\title{
珊瑚由来の石灰石骨材が海水練り自己充塡型 コンクリートの性質に及ぼす影響
}

\author{
竹中 寛 $1 \cdot$ 谷口 修 $2 \cdot$ 田中 亮一 3 与 与那嶺 一秀 $4 \cdot$ 山路 徹 $5 \cdot$ 清宮 理 6 \\ 1正会員 東洋建設株式会社 美浦研究所（†300-0424 茨城県稲敷郡美浦村受領 1033-1） \\ E-mail: takenaka-hiroshi@toyo-const.co.jp \\ 2 正会員 五洋建設株式会社 技術研究所（†329-2746 栃木県那須塩原市四区町 1534-1） \\ E-mail: osamu.taniguchi@mail.penta-ocean.co.jp \\ 3 正会員 東亜建設工業株式会社 技術研究開発センター（干230-0035 神奈川県横浜市鶴見区安善町 1-3） \\ E-mail: ryo_tanaka@toa-const.co.jp \\ 4 正会員＼cjkstart港湾空港技術研究所（干239-0826 神奈川県横須賀市長瀬 3-1-1） \\ E-mail: yamaji-t@p.mpat.go.jp \\ 5 正会員 港湾空港技術研究所（干239-0826 神奈川県横須賀市長瀬 3-1-1） \\ E-mail: yonamine-k@p.mpat.go.jp \\ 6 正会員 早稲田大学名誉教授（干169-0072 東京都新宿区大久保 3-4-1） \\ (現一般財団法人沿岸技術研究センター) \\ E-mail: kiyomiya@cdit.or.jp
}

\begin{abstract}
本研究では，遠隔離島で活用するコンクリートを想定し，海水，珊瑚由来の石灰石骨材および特殊混和 剂を用いた自己充填型コンクリートの基礎的性質, 収縮特性, 熱的性質および而摩耗性について実験的検 討を行った。その結果，コンクリート用材料として空隙が多い珊瑚由来の石灰石骨材を用いた場合におい ても，優れた流動性と適度な材料分離抵抗性を有する自己充填型コンクリートを製造することができ，普 通骨材を用いた場合と同等程度の強度発現性を有すること，収縮ひずみや熱膨張係数が小さくなることな どを明らかにした。また，水セメント比や単位粗骨材容積を小さく設定すれば，普通骨材と同等の而摩耗 性を確保できることがわかった。
\end{abstract}

Key Words : seawater, coral aggregate, self-compacting concrete, compressive strength, shrinkage, thermal expansion coefficient, abrasion resistance

\section{1. 序章}

本土からのアクセスが悪い国内外の離島においては, 上水道水や骨材などの材料調達や，建設労働者の確保が 困難になることが想定される。このような条件下でコン クリートを製造・施工する場合，できるかぎり施工場所 の近傍で調達可能な材料を使用すること，コンクリート の構成材料の種類を最小限に抑え，容易に製造できるこ と，また，自己充塡性を有するコンクリートを使用して 締固め作業を省力化し，施工効率を向上寸ることなどが 求められる.

著者らは，離島等における無筋・鉄筋コンクリート構 造物を対象として，上記の要求を満たすべく，従来の高 流動コンクリートに比べて粘性の低い，海水と未洗浄の
海砂を使用した自己充填型コンクリートを開発・検討し てきた ${ }^{1)}$. コンクリートの練混ぜ水に海水を使用する場 合, 海水中に含まれる無機イオン（主に塩化物イオン） が混和剤の分散性を阻害するため, 従来, コンクリート に優れた流動性を付与寸ることが困難であったが，当該 コンクリートでは，新たに開発した無機イオンの影響を 受けにくい特殊混和剤を用いることで，この課題を改善 している ${ }^{2}$. また，鉄筋コンクリート構造物へ適用する にあたっては，耐食性の高いステンレス鉄筋等の併用を 想定している1).

ところで，日本本土の南方には，珊瑚が化石化した石 灰岩が多く堆積している．そのような地域の遠隔離島で は，現地で調達できる海水と珊瑚由来の石灰岩から製造 する細・粗骨材（以下，珊瑚骨材と称す）を，コンクリ 
一ト用材料として用いることが経済性や製造効率の観点 で望ましい，また，前述したように，自己充填性を有す るコンクリートを使用することで，さらに施工の省力化 も図れると期待できるが，これらの材料を組み合わせた 自己充䪺型コンクリートについては, これまでに検討さ れた実績がない。

そこで，本研究では，海水および珊瑚骨材を用いた自 己充填型コンクリートの諸特性を明らかにす心゙く, 珊瑚 骨材の特徴，それを用いたコンクリートの基礎的性質 3), 収縮特性 ${ }^{4}$, 熱的性質および而摩耗性について実験的検 討を行った. 本稿では, これらの検討で得られた知見を もとに, 珊瑚骨材の物理的性質, 形状および空隙構造が コンクリートの諸性状に及ぼす影響について考察する.

\section{2. 珊瑚由来の石灰石骨材の特徵}

\section{(1) 物理的性質}

本研究で使用した珊瑚骨材は，遠隔離島で採取した 石灰岩を，破砕・分級したものであり，5 mm 以下の骨 材を細骨材（以下，珊瑚細骨材と称寸），5〜25 mm の 骨材を粗骨材（以下，珊瑚粗骨材と称寸）とした．珊瑚 骨材は，一部茶褐色に変色しているものも見受けられた が，ほとんどが白色を呈している.

細骨材と粗骨材の物性值および粒度分布を，それぞ れ表-1, 図-1 に示す。これらの結果より, 珊瑚骨材は, 比較用の普通細・粗骨材（以下，普通骨材と称寸）に比 べて微粒分量が多い，吸水率が大きい，粗骨材が脆い （すりへり減量が大きい）などの特徴を有し，また，写 真-1 に示寸とおり, 粗骨材の形状や外観は多様で, 内 部に空隙を有するものが多く存在していた.

粗骨材の粒子毎の表乾密度と吸水率の関係を図-2 に, それぞれの度数分布を図-3に示寸。これらの図より， 珊瑚骨材のほうが普通骨材に比べてばらつきの大きいこ とが分かり, 普通骨材の表乾密度と吸水率の標準偏差が それぞれ $0.05 \mathrm{~g} / \mathrm{cm}^{3}$ (平均值 : $2.65 \mathrm{~g} / \mathrm{cm}^{3}$ ) と $0.19 \%$ (平均 值 : $0.45 \%)$ であったのに対し, 珊瑚骨材では $0.24 \mathrm{~g} / \mathrm{cm}^{3}$ (平均值 : $2.29 \mathrm{~g} / \mathrm{cm}^{3}$ ) と $4.24 \%$ (平均值 : $4.70 \%$ ) であ った。 なお，これらの試験に供した試料は，表-1 の密 度・吸水率試験の試料とは異なり, $15 \mathrm{~mm}$ 以上の珊瑚骨 材と普通骨材をそれぞれ任意に約 200 個ずつ選定し， 個々の粒子の表乾状態の気中質量 - 水中質量, 乾燥 $\left(105^{\circ} \mathrm{C}, 24\right.$ 時間) 後の気中質量加算定した.

\section{(2) 成分}

蛍光 X 線分析による珊瑚粗骨材の構成成分を図-4に 示寸. 図より, $\mathrm{Ca}$ と $\mathrm{O}$ の元素が多く含まれていること から, 珊瑚骨材の主成分は炭酸カルシウムであると推定
表-1 骨材の物性值

\begin{tabular}{|c|c|c|c|c|}
\hline & \multicolumn{2}{|c|}{ 細骨材 } & \multicolumn{2}{|c|}{ 粗骨材 } \\
\hline & $\begin{array}{c}\text { 珊瑚 } \\
(\text { 砕砂) }\end{array}$ & $\begin{array}{c}\text { 普通 } \\
\text { (陸砂) }\end{array}$ & $\begin{array}{c}\text { 珊瑚 } \\
\text { (砕石) }\end{array}$ & $\begin{array}{c}\begin{array}{c}\text { 普通 } \\
(\text { 砕石) }\end{array} \\
\end{array}$ \\
\hline 表乾密度 $\left(\mathrm{g} / \mathrm{cm}^{3}\right)$ & 2.60 & 2.60 & 2.40 & 2.66 \\
\hline 絶乾密度 $\left(\mathrm{g} / \mathrm{cm}^{3}\right)$ & 2.52 & 2.55 & 2.28 & 2.64 \\
\hline 吸水率（\%） & 3.30 & 1.86 & 5.13 & 0.58 \\
\hline 粗粒率 & 2.53 & 2.66 & 6.14 & 6.71 \\
\hline 微粒分量（\%） & 14.8 & 1.2 & 3.6 & 0.1 \\
\hline 実積率（\%） & 68.1 & 67.8 & 62.5 & 62.8 \\
\hline 安定性損失量（\%） & 1.6 & 0.9 & 3.3 & 0.9 \\
\hline 粘土塊量（\%） & 0.52 & 0.05 & 0.15 & 0.05 \\
\hline 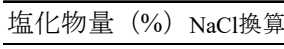 & 0.043 & 0 & 0.007 & - \\
\hline 軟石質量分率（\%） & - & - & 40.5 & - \\
\hline すりへり減量 $(\%)$ & - & - & 29.4 & 16.4 \\
\hline 破砕値（\%） & - & - & 36.9 & - \\
\hline
\end{tabular}

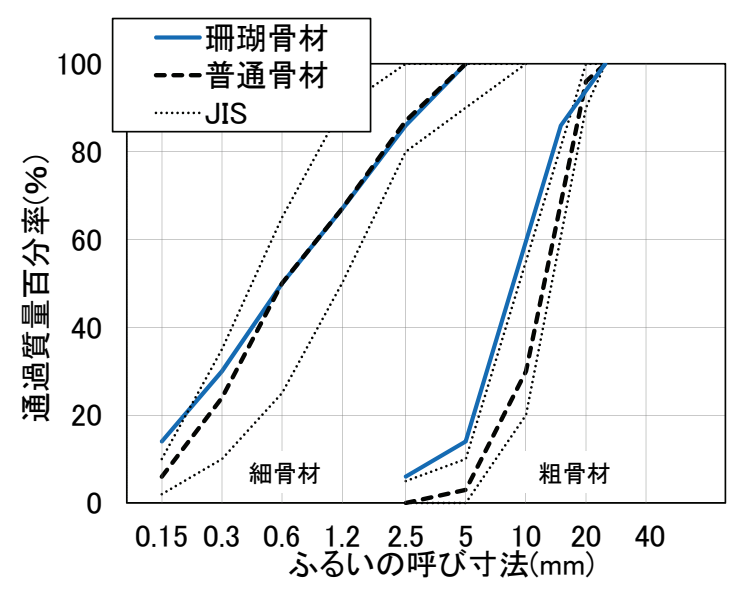

図-1 骨材の粒度分布
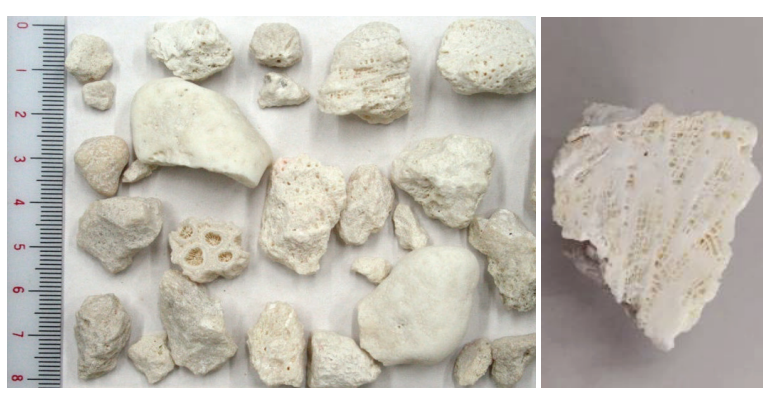

写真-1 珊瑚粗骨材

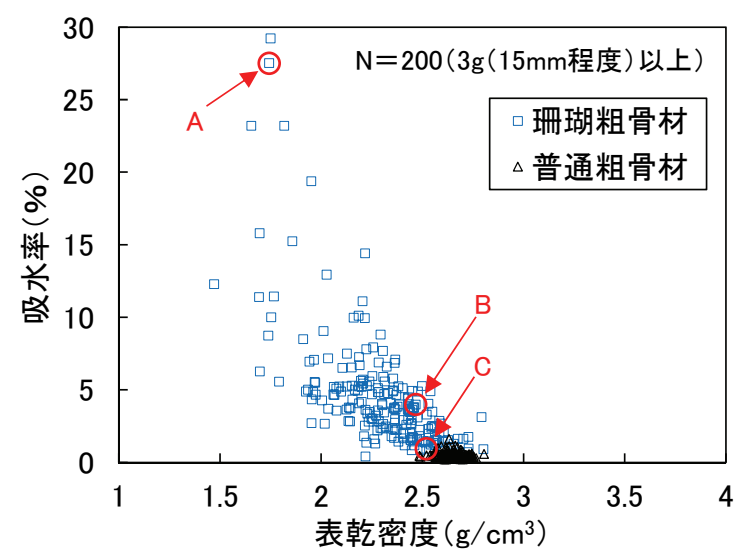

図-2 粗骨材の表乾密度と吸水率の関係 


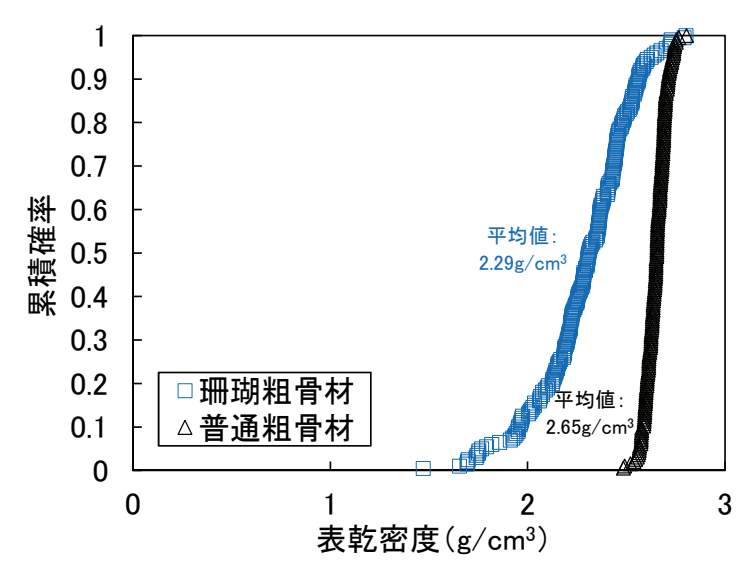

(a) 表乾密度

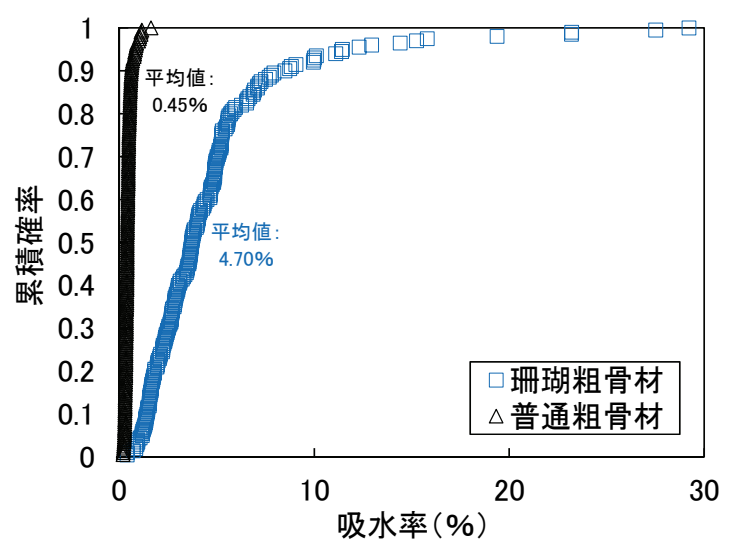

(b) 吸水率

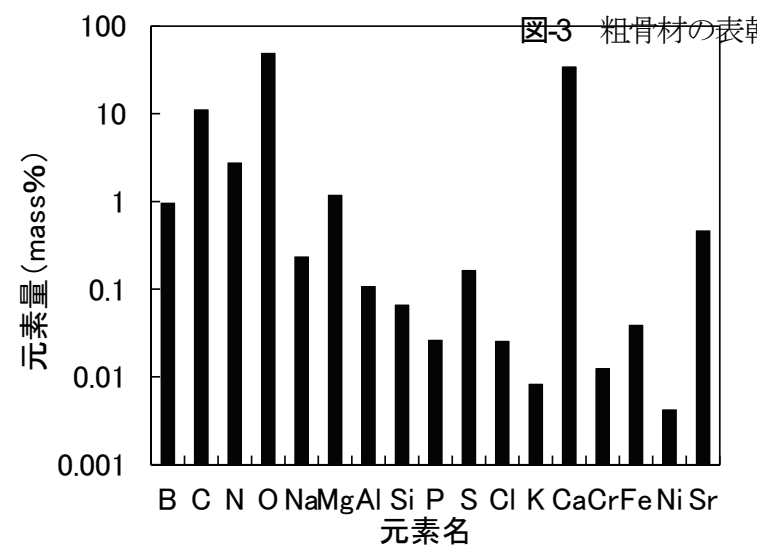

図-4 珊瑚粗骨材の構成成分

される.

\section{(3) 空隙構造}

マイクロスコープにより観察した珊瑚粗骨材の拡大像 を写真-2 に示寸，左端の記号は図-2 に示寸 A (吸水率 $27.5 \%$ ），B（吸水率 $4.0 \%$ ）およびC（吸水率 $0.9 \%$ ）を 意味する，骨材 $\mathrm{A}$ は， $0.1 \sim 0.2 \mathrm{~mm}$ 程度の空隙が網状に 多く存在していたのに対し，骨材 C では，空陌は僅か であった，一方，平均的な品質を有する骨材 B につい ても，骨材 A と同様に内部に空隙を多く有していたが, 0.2 1 mm 程度の比較的大きく不規則な孔が連続的に存 在するなど，形態には相違がみられた。

このように，粒子間で空隙構造に違いはあるものの， 総じて多くの空隙を有している. 内部に空隙を有する骨 材の一つとして人工軽量骨材がある。人工軽量骨材には, $40 \mathrm{~nm}$ 以下の空隙において, 一般的な骨材（砂岩砕石 等）では認められないインクボトル空隙（ボトルネック 構造で水分の移動が抑制される空隙）が存在すると報告 されている 5. 本研究では, 珊瑚骨材におけるインクボ トル空隙の有無を確認すべく，既往の文献 5)を参考に水 銀漸次繰返し圧入法による試験を行った。試料には 5 $\mathrm{mm}$ 程度に粉砕した珊瑚粗骨材を用い，表-2 に示寸圧入 過程で水銀圧入式ポロシメータにより細孔径分布を測定

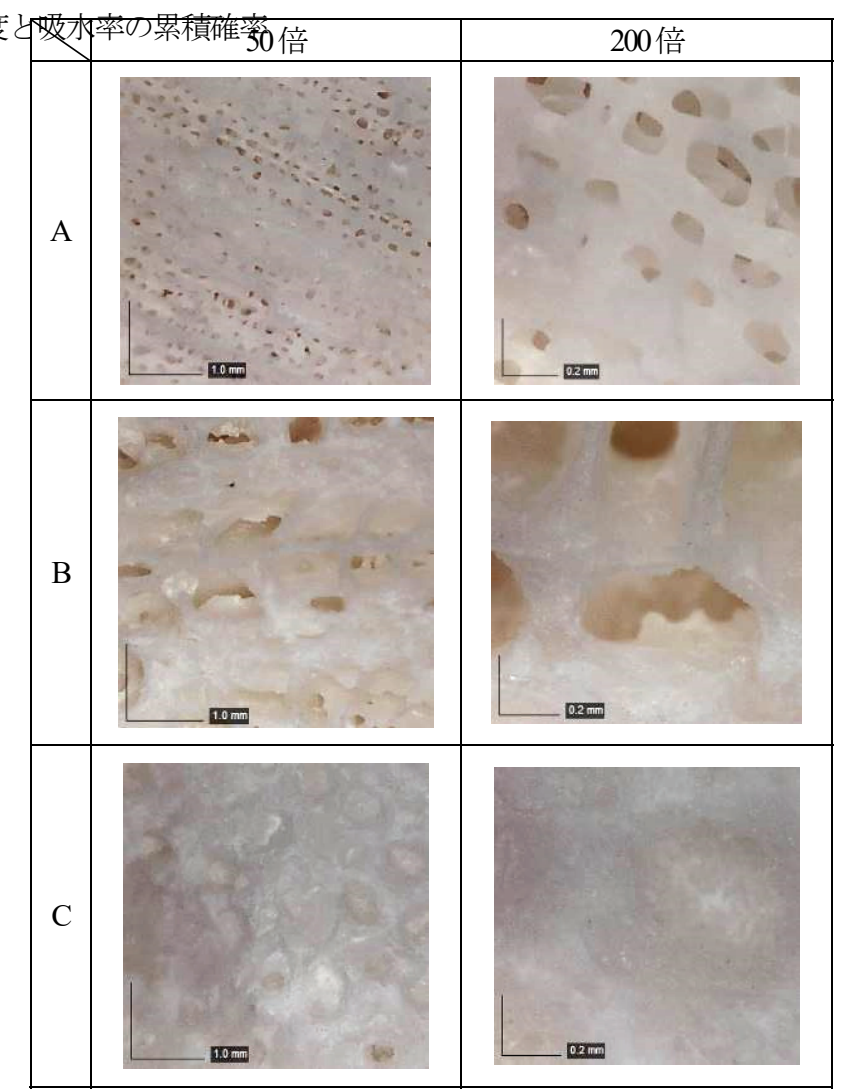

写真-2 珊瑚粗骨材の拡大像

表-2 圧入圧力と換算空隙径

\begin{tabular}{c|ccc}
\hline 過程 & \multicolumn{2}{|c|}{$\begin{array}{c}\text { 圧入圧力 }(\mathrm{MPa}) \\
{[\text { 換算空隙直径 }(\mu \mathrm{m})]}\end{array}$} \\
\hline \hline 1 & $0.04[33]$ & $\rightarrow$ & $1[1.1]$ \\
\hline 2 & $0.3[3.9]$ & $\rightarrow$ & $4[0.32]$ \\
\hline 3 & $0.3[3.9]$ & $\rightarrow$ & $13[0.1]$ \\
\hline 4 & $0.3[3.9]$ & $\rightarrow$ & $19[0.07]$ \\
\hline 5 & $0.3[3.9]$ & $\rightarrow$ & $31[0.04]$ \\
\hline 6 & $0.3[3.9]$ & $\rightarrow$ & $58[0.02]$ \\
\hline
\end{tabular}

した.

累計空隙曲線を図-5 に示寸，(b)は，(a)の圧入曲線の 4 $\mu \mathrm{m}$ における圧入量が 0 となるように曲線を水平移動さ せたものであり, 圧入曲線の重複部が連続空隙, 分岐部 


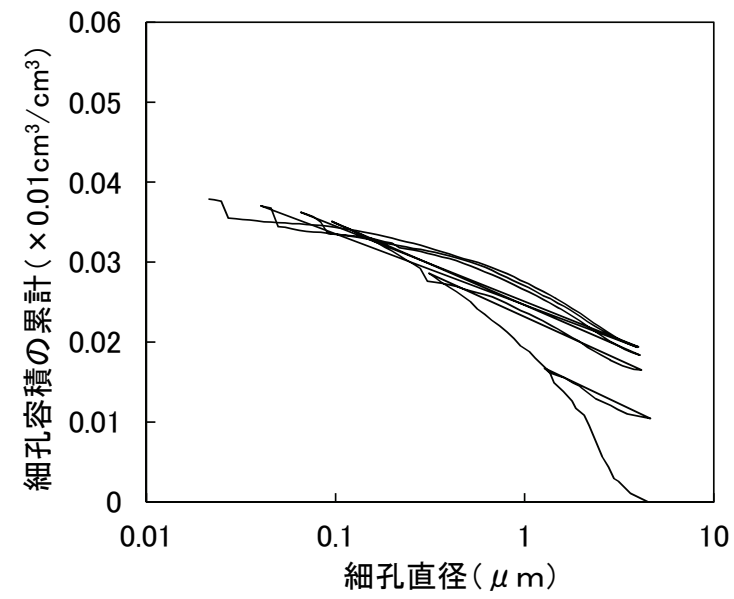

(a) 圧入量履歴

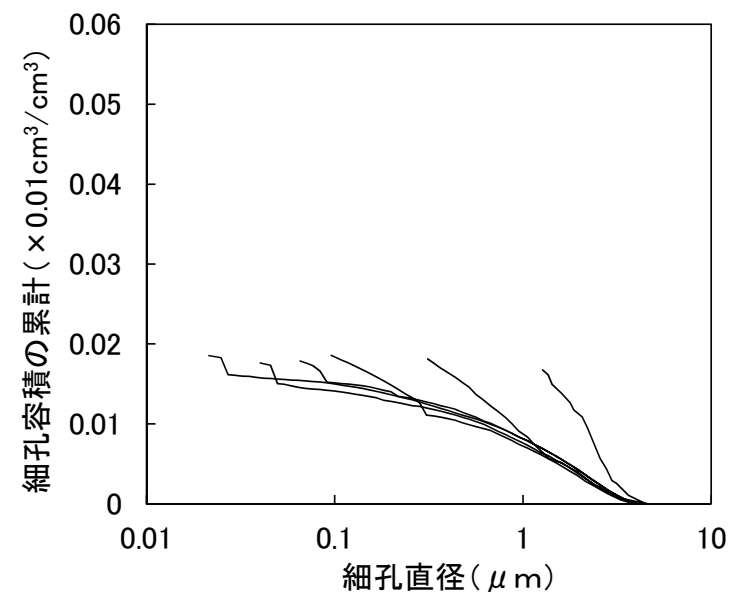

(b) 残留圧入量補正

図-5 累計空隙曲線

表-3 コンクリートの配合

\begin{tabular}{|c|c|c|c|c|c|c|c|c|c|c|c|c|c|c|c|c|}
\hline \multirow[b]{2}{*}{ No. } & \multirow[b]{2}{*}{ 記号 } & \multirow[b]{2}{*}{$\begin{array}{l}\text { W/C } \\
(\%) \\
\end{array}$} & \multirow[b]{2}{*}{$\begin{array}{l}\mathrm{s} / \mathrm{a} \\
(\%) \\
\end{array}$} & \multirow{2}{*}{$\begin{array}{l}\text { 単位粗 } \\
\text { 骨材絶 } \\
\text { 対容積 } \\
\left(\mathrm{m}^{3} / \mathrm{m}^{3}\right) \\
\end{array}$} & \multicolumn{7}{|c|}{ 単位量 $\left(\mathrm{kg} / \mathrm{m}^{3}\right)$} & \multicolumn{3}{|c|}{ 混和剤 $(\mathrm{C} \times \%)$} & \multirow[b]{2}{*}{$\begin{array}{l}\text { 環境 } \\
\text { 温度 } \\
\left({ }^{\circ} \mathrm{C}\right) \\
\end{array}$} & \multirow[b]{2}{*}{$\begin{array}{c}\text { 塩化物 } \\
\text { イオン量 } \\
\left(\mathrm{kg} / \mathrm{m}^{3}\right)\end{array}$} \\
\hline & & & & & $\begin{array}{l}\text { 上水 } \\
\mathrm{TW}\end{array}$ & $\begin{array}{c}\text { 海水 } \\
\text { SW }\end{array}$ & $\begin{array}{c}\text { セメント } \\
\mathrm{C}\end{array}$ & \begin{tabular}{|c|c} 
普通 \\
細骨材 \\
NS \\
\end{tabular} & \begin{tabular}{|c|c|} 
珊瑚 \\
細骨材 \\
CS \\
\end{tabular} & \begin{tabular}{|c|c} 
普通 \\
粗骨材 \\
NG \\
\end{tabular} & $\begin{array}{c}\text { 珊瑚 } \\
\text { 粗骨材 } \\
\text { CG } \\
\end{array}$ & Ad1 & Ad2 & $\mathrm{Ad} 3$ & & \\
\hline \multirow{2}{*}{1} & \multirow{2}{*}{ SW-CA } & \multirow{4}{*}{45} & \multirow{2}{*}{50.8} & \multirow{2}{*}{0.315} & \multirow{2}{*}{-} & \multirow{2}{*}{185} & \multirow{2}{*}{411} & \multirow{2}{*}{-} & \multirow{2}{*}{845} & \multirow{2}{*}{-} & \multirow{2}{*}{756} & 1.25 & - & - & 20 & \multirow{2}{*}{3.71} \\
\hline & & & & & & & & & & & & - & 1.35 & 1.00 & 35 & \\
\hline 2 & SW-NA & & 49.7 & \multirow{2}{*}{0.330} & - & 175 & 389 & 848 & - & 878 & - & 1.65 & - & - & $\frac{20}{35}$ & 3.20 \\
\hline 3 & TW-NA & & 49.7 & & 175 & - & 389 & 848 & - & 878 & - & 1.45 & - & - & $\frac{20}{35}$ & 0.05 \\
\hline
\end{tabular}

がインクボトル空隙を意味する. 図より，圧入曲線に分 岐部が認められ，珊楜粗骨材にもインクボトル空隙が存 在することを示唆する結果となったが，その空隙量（図 -5 (b)の分岐線の上端值) は $0.02 \times 0.01 \mathrm{~cm}^{3} / \mathrm{cm}^{3}$ であり，既 往の人工軽量骨材の空隙量の $1 / 10$ 程度であった.

以上のように，珊瑚粗骨材には微細なものから粗大な ものまで，幅広い径の空隙が多く存在していることが明 らかとなった．このような空隙を有する骨材をコンクリ ートに用いた場合，フレッシュコンクリートでは加圧吸 水に伴う性状の変化, 硬化コンクリートでは強度の低下 や収縮等による体積変化の増加が䀣念される.また，骨 材空隙の存在による蓄熱の増加に加え, 海水に起因した セメントの水和促進により温度ひび割れを助長する恐れ がある. さらに, 当該コンクリートを海中に没する構造 物一適用することを想定した場合には，而摩耗性の低下 が危惧されることから，これらの特性を把握すべく，次 章以降に詳述寸る検討を行った。

\section{3. コンクリートの基礎的性質}

\section{(1) 実験概要}

\section{a) 配合および使用材料}

コンクリートの配合を表-3 に示す．配合は，練混ぜ
水に海水，骨材に珊瑚骨材を用いた配合（SW-CA）， 練混ぜ水と骨材に海水と普通骨材を用いた配合（SWNA），上水道水と普通骨材を用いた配合（TW-NA）の 全 3 水準とし, それぞれ標準温度 $\left(20^{\circ} \mathrm{C}\right)$ と高温度 $\left(35^{\circ} \mathrm{C}\right)$ の環境条件下で試験を行った。 コンクリートの 水セメント比は $45 \%$ で一定とし，スランプフローが 600 $\pm 50 \mathrm{~mm}$, 空気量が $4.5 \pm 1.5 \%$ 範囲となるよう, 単位 水量, 混和剂の添加率 $(\mathrm{C} \times 2.0 \%$ を限 $)$ および細骨材 率を調整した．本研究で用いた珊瑚骨材は，普通骨材に 比べて微粒分量が多いことなどが起因して，同じスラン プフローとなるための単位水量は, SW-CA が他の 2 配 合に比べて多くなった. また, $35^{\circ} \mathrm{C}$ 高温環境の場合, 時間の経過に伴い流動性が急激に低下したため, 流動性 の経時保持性を向上すべく, SW-CA では混和剂を遅延 型のものに切り替え, さらに流動性保持剂を併用した. なお，各配合の塩化物イオン量（配合上の計算值）は, 表中に併記したとおりである.

コンクリートの使用材料を表-4 に示す. 練混ぜ水に 用いた海水は相模湾で採水し，海水中に質量比で $1.8 \%$ 程度の塩化物イオンを含有していた. 海水の成分は表-5 に示すとおりである. セメントは高炉セメント B 種と し，骨材には，前章で述べた珊瑚骨材と普通骨材（表-1 参照）を用いた，なお，いずれの骨材も事前に十分な吸 水を行い, 表面水率（姍瑚骨材： $+1 \sim 2 \%$ ） から水量を 
表-4 コンクリートの使用材料

\begin{tabular}{|c|c|c|c|}
\hline 材料名 & 記号 & 種類 & 物理的·化学的性質 \\
\hline \multirow{2}{*}{ 練混ぜ水 } & TW & 上水道水 & \\
\hline & SW & 海水（相模湾） & 表-5参照 \\
\hline セメント & $\mathrm{C}$ & 高炉セメントB種 & 密度 $3.04 \mathrm{~g} / \mathrm{cm}^{3}$ \\
\hline \multirow{2}{*}{ 細骨材 } & NS & 陸砂（大井川水系） & 表-1参照 \\
\hline & $\mathrm{CS}$ & 珊瑚砕砂（遠隔離島産） & 同上 \\
\hline \multirow{2}{*}{ 粗骨材 } & NG & 硬質砂岩砕石（青梅産） & 同上 \\
\hline & $\mathrm{CG}$ & 珊瑚砕石（遠隔離島産） & 同上 \\
\hline \multirow{3}{*}{ 混和剤 } & Ad 1 & $\begin{array}{l}\text { 塩分含有用増粘剤一液型 } \\
\text { 高性能AE減水剂 (標準型) }\end{array}$ & $\begin{array}{l}\text { ポリカルボン酸エーテル系化合物 } \\
\text { と増粘性高分子化合物の複合体 }\end{array}$ \\
\hline & $\operatorname{Ad} 2$ & 同上(遅延型) & 同上 \\
\hline & Ad3 & 流動性保持剤 & ポリカルボン酸エーテル系化合物 \\
\hline
\end{tabular}

表-5 海水の成分

\begin{tabular}{|c|c|c|c|c|c|}
\hline \multicolumn{2}{|c|}{$\begin{array}{c}\text { 密度 }\left[20^{\circ} \mathrm{C}\right] \\
\left(\mathrm{g} / \mathrm{cm}^{3}\right)\end{array}$} & $\begin{array}{c}\mathrm{pH} \\
{\left[20^{\circ} \mathrm{C}\right]} \\
\end{array}$ & \multicolumn{3}{|c|}{$\begin{array}{c}\text { 固形分濃度 }\left[105^{\circ} \mathrm{C}, 3 \mathrm{hr}\right] \\
(\%)\end{array}$} \\
\hline \multicolumn{2}{|c|}{$1.022 \sim 1.025$} & 8.0 & \multicolumn{3}{|c|}{$3.48 \sim 3.70$} \\
\hline \multicolumn{6}{|c|}{ 各種イオンの含有量 $(\%)$} \\
\hline $\mathrm{Cl}^{-}$ & $\mathrm{SO}_{4}^{2-}$ & $\mathrm{Na}^{+}$ & $\mathrm{K}^{+}$ & $\mathrm{Ca}^{2+}$ & $\mathrm{Mg}^{2+}$ \\
\hline $1.75 \sim 1.80$ & $0.23 \sim 0.26$ & $1.08 \sim 1.19$ & $0.03 \sim 0.04$ & $0.04 \sim 0.05$ & 0.12 \\
\hline
\end{tabular}

表-6 試験項目および方法

\begin{tabular}{|c|c|c|}
\hline 試験項目 & 試験方法 & 試験条件等 \\
\hline "スランプフロー & JIS A 1150 & 測定時期：練混ぜ後 $0,30,60,90$ 分 \\
\hline 空気量 & \begin{tabular}{|l|} 
JIS A 1128 \\
JIS A 1116 \\
\end{tabular} & 珊瑚骨材の配合は質量法にて測定 \\
\hline 充填高さ・時間 & JSCE-F 511 & $\begin{array}{l}\text { 流動障害: R2 } \\
\text { 充填時間：充填停止時 }\end{array}$ \\
\hline 加圧ブリーディング & JSCE-F 502 & \\
\hline 圧縮強度 & JIS A 1108 & $\begin{array}{l}\text { 養生条件: }: 20^{\circ} \mathrm{C} \text { または } 35^{\circ} \mathrm{C} \text { 水中養生 } \\
\text { 試験材齢 : } 1,3 ， 7 ， 28 \text { 日 }\end{array}$ \\
\hline 静弾性係数 & JIS A 1149 & 養生条件：同上 試験材齢：7，28日 \\
\hline
\end{tabular}

補正して練混ぜを行った，混和剤には，特殊混和剤を使 用した。また，SW-CA に使用した流動性保持剂は，ポ リカルボン酸系のものであり, 強い減水効果は示さない ものの，流動性の経時保持性に優れるところにその特徴 がある.

\section{b) 試験項目および方法}

コンクリートの試験項目の一覧を表-6 に示寸．スラ ンプフローは, 練混ぜ完了後に試験を行った後, 試料を 静置した状態で, 最長 90 分まで経時変化を確認した. また，珊瑚骨材は，人工軽量骨材などと同様に 0，加圧 吸水する傾向が認められたため, 珊瑚骨材を用いた配合

（SW-CA）については圧力法ではなく質量法にて空気 量を測定した。圧縮強度試験の供試体は，材齢 1 日まで 練混ぜ時と同じ温度環境下で封緘養生を行った後に脱型 し，その後も同じ温度の水中において所定の材齢まで養 生を行った.

\section{(2) 実験結果および考察}

\section{a）コンクリートの流動性・自己充塡性}

海水および珊瑚骨材を用いた配合（SW-CA）におけ る，コンクリートの練混ぜ完了後からの経過時間とスラ ンプフローの関係を図-6 に示す. $20^{\circ} \mathrm{C}$ と $35^{\circ} \mathrm{C}$ のずれ の環境においても，90 分後までスランプフローの目標

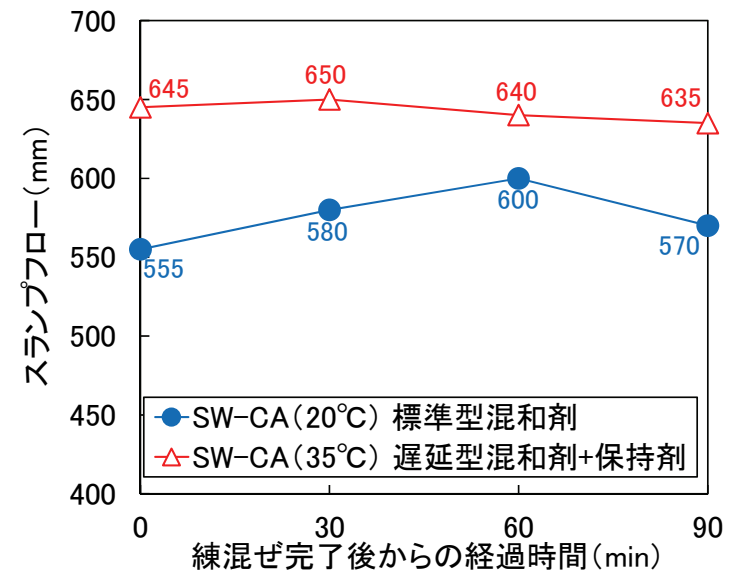

図-6 スランプフローの経時変化

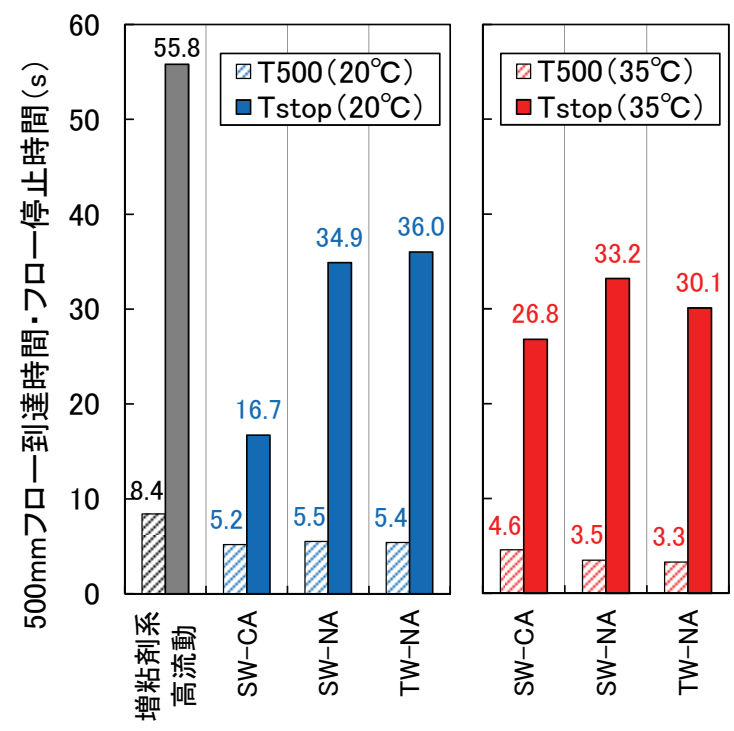

図-7 スランプフロー時間

範囲 $(600 \pm 50 \mathrm{~mm})$ を満足した. $35^{\circ} \mathrm{C}$ 高温環境におい ても，遅延型の混和剤と流動性保持剤を併用すれば，海 水や珊瑚骨材を用いた場合でも所要の性能を保持できる ことがわかった。

練混ぜ完了後の $500 \mathrm{~mm}$ フロー到達時間（T500）と停 止時間（Tstop）を図-7 に示寸．本研究で検討した配合 は, $20^{\circ} \mathrm{C}$ と $35^{\circ} \mathrm{C}$ のずれの環境においても, 図に併記 した従来の増粘剤系の高流動コンクリートわに比べて T500, Tstop が短くなる, 寸なわち粘性が小さくなる傾

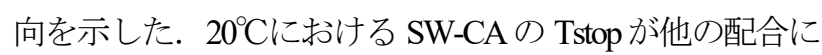
比べて小さくなっているが，これは，スランプフローが 小さかったこと, 増粘剤を含有する混和剤の添加量が他 に比べて少なく，粘性が低下したことなどが要因と考え られる。

U 形充填試験における，コンクリートの充墴高さおよ び充填時間を図-8 に示寸，全ての配合において充填高 さは $300 \mathrm{~mm}$ 以上を示し, 自己充填性レベルは, ランク 

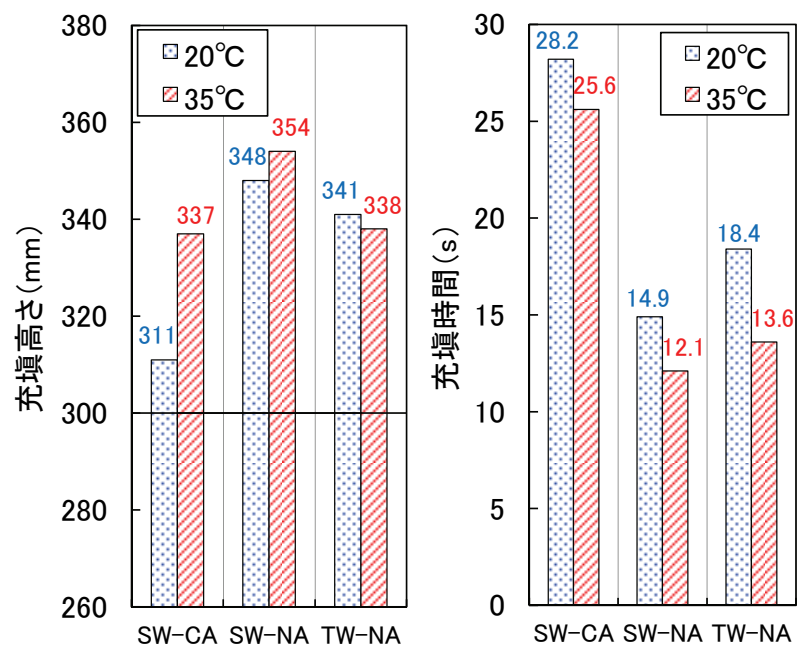

図-8 U形充填高さ・時間

2 を満足した。海水およひ珊瑚骨材を用いた配合（SWCA）は，他の配合に比べてモルタルの量が多いにもか かわらず充塡高さがやや小さく，充塡時間がやや長くな る傾向を示した．これは，前述したようにフローが小さ かったこと $\left(20^{\circ} \mathrm{C}\right)$ や粘性が低下ことなども一因と考え られるが，珊瑚粗骨材の形状にばらつきが大きく，障害 の近傍で閉塞しやすくなっていたことが主要因であると 推察される. なお，ほとんどの配合で， $20^{\circ} \mathrm{C}$ より $35^{\circ} \mathrm{C}$ のほうが，充塡時間が短く，充填高さが大きくなってい るが，これは，フローが大きかったこと，環境温度の上 昇に伴いコンクリートの粘性が小さくなったことなどが 要因と推察される.

\section{b) 加圧時の吸水特性}

加圧ブリーディング試験における，加圧後の経過時間 と脱水量の関係を図-9 に示寸，普通骨材を用いた配合 （TW-NA，SW-NA）の脱水量は，コンクリートのポン パビリティが良好であると判断される，標準曲線 B と C の範囲 3)内に入ったのに対し，珊瑚骨材を用いた配合 （SW-CA）は，上記の範囲をやや下方に逸する結果と なったこれは，内部に空隙（常圧下で水が満たされに くい空隙など）を有する珊瑚骨材の加圧吸水が影響した ためと推察される. 既往の研究においても, 常圧下で水 中浸漬しただけでは珊瑚骨材を飽水状態にすることは困 難であり，骨材の加圧吸水によりポンプ圧送性が低下寸 ることが示唆されている ${ }^{8}$. 本研究のコンクリートは流 動性に優れるため, スランプレベルの普通コンクリート に珊瑚骨材を用いる場合に比べれば，ポンパビリティの 低下に伴うリスクは小さいと考えられるが，圧送を行う 際は，コンクリートが閉塞しないよう配管長や吐出量を 調整するなど，留意が必要である.

\section{c) 強度発現性}

コンクリートの材齢と圧縮強度の関係を図-10 に示寸. 環境温度によって強度発現性は異なるが，海水を用いた

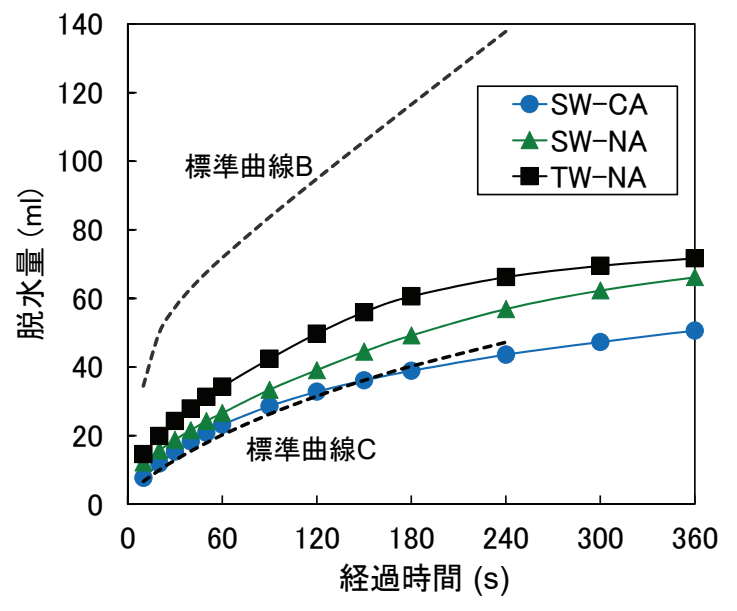

図-9 加圧時の脱水量の経時変化

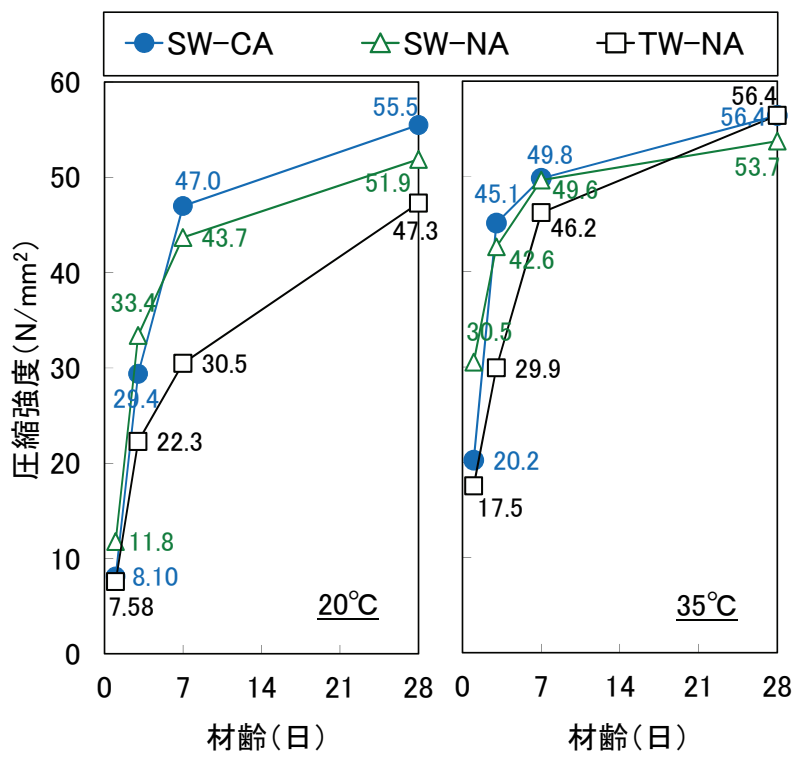

図-10 圧縮強度

配合（SW-NA，SW-CA）の方が，骨材の種類を問わず， 上水道水を用いた配合（TW-NA）に比べて初期材齢の 圧縮強度が大きくなる傾向を示した．海水を用いてコン クリートを製造した場合，塩化ナトリウムなどにより硬 化が促進されることが既往の研究 1)9 ‘゙示唆されており, 本研究の結果もそれに符合寸るものと考えられる。 また, 海水を用いた配合のうち， $35^{\circ} \mathrm{C}$ 環境の珊瑚骨材を用いた 配合（SW-CA）の材齢 1 日における圧縮強度が，同環境 で普通骨材を用いた配合（SW-NA）に比べて小さくな っている.この要因としては，その後材齢の経過ととも に強度が増加し，材齢 3 日以降では SW-NA と同等の強 度となることから，遅延型の混和剤を用いたことによる コンクリートの硬化遅延と推察される. なお, 各材齢の 圧縮強度はそれぞれ 3 本の供試体の平均值を用いている。 標準偏差は，普通骨材の配合（SW-NA，TW-NA）では 大 $0.8 \mathrm{~N} / \mathrm{mm}^{2}$ であったのに対し, 珊瑚骨材の配合では最 大 $2.2 \mathrm{~N} / \mathrm{mm}^{2}$ とやや大きかったが，供試体間の過大なば らつきは認められなかった。 
以上のように，本研究の範囲では，珊瑚骨材を用いた コンクリートの圧縮強度は，普通骨材を用いた場合に比 ベて低下する傾向は認められなかった． 既往の文献 ${ }^{10} に$ よると，コンクリートの圧縮強度は，モルタルの圧縮強 度が粗骨材の圧縮強度に比べて大きい場合，粗骨材の圧 縮強度に依存するが，モルタルの圧縮強度が粗骨材の圧 縮強度に比べて小さい場合，粗骨材の圧縮強度への依存 性は小さいとされている.この文献では，本研究で用い た珊瑚粗骨材と類似の性質を有すると推察される珊瑚礁 堆積物粗骨材（砕石）も検討対象としている.この試験 結果によると，水結合材比が $40 \%$ 以上の配合では粗骨 材の圧縮強度がモルタルの圧縮強度より大きくなるため, 珊瑚礁堆積物粗骨材よりも圧縮強度が大きい硬質砂岩粗 骨材 (砕石) と比較してもコンクリートの圧縮強度とし ては差異のないことが示されている. 本研究で使用した 珊瑚粗骨材の圧縮強度は不明であるが，前記文献 ${ }^{10)}$ にお ける珊瑚由来の粗骨材（珊瑚れき, 珊瑚砕石）の圧縮強 度（微小圧縮強度）の平均值が $60 \mathrm{~N} / \mathrm{mm}^{2}$ 程度であった こと, 本研究の珊瑚粗骨材と同等のすり減り減量となる, 他の文献 11) で用いた石灰質の骨材のそれが 40〜65 $\mathrm{N} / \mathrm{mm}^{2}$ 程度であったことから，本研究の珊瑚粗骨材もこ れらと同程度の圧縮強度を有していたと推察される。こ のように仮定すると, 珊瑚粗骨材の圧縮強度は, 水セメ ント比 $45 \%$ の本研究のモルタル強度（6章で後述）と同 程度となるため, 粗骨材の種類の違いがコンクリートの 圧縮強度に現れにくい領域（粗骨材強度が影響しない上 限付近）であったものと考えられる. また，他の文献 ${ }^{11)}$ では，形状が悪く実積率の小さな石灰質の粗骨材を用い たコンクリートは, 単位水量の増加や, それに起因する ブリーディングの増加により，普通骨材の粗骨材（以下， 普通粗骨材と称す）を用いた場合に比べて強度が低下す ると考察されている.しかしながら，本研究の結果では， 前述のとおり珊瑚粗骨材を用いたコンクリートの圧縮強 度が普通粗骨材のものに比べて低下する傾向は認められ

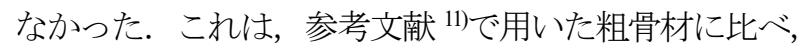
今回用いた珊瑚粗骨材の実積率が大きかったことも一因 と考えられるが，本研究のコンクリートの場合は，混和 剤中の増粘剤のはたらきによりブリーディングなどの材 料分離が最小限に抑えられ，粗骨材の種類の違いによる 影響が現れにくかったことも一因と考えられる. なお, 本研究で用いた珊瑚骨材と同様に，吸水率の大きい再生 骨材を用いたコンクリートでは，その圧縮強度には細骨 材の影響が大きく，収縮には粗骨材の影響が大きくなる という報告 ${ }^{12)}$ もる.

コンクリートの圧縮強度と静弾性係数の関係を図-11 に示す. 図中の值は, 各配合の材齢 7, 28 日における全 供試体（20ㅇおよび $35^{\circ} \mathrm{C}$ 環境）の結果であり，同図に 併記した計算值は，2017 年度制定コンクリート標準示

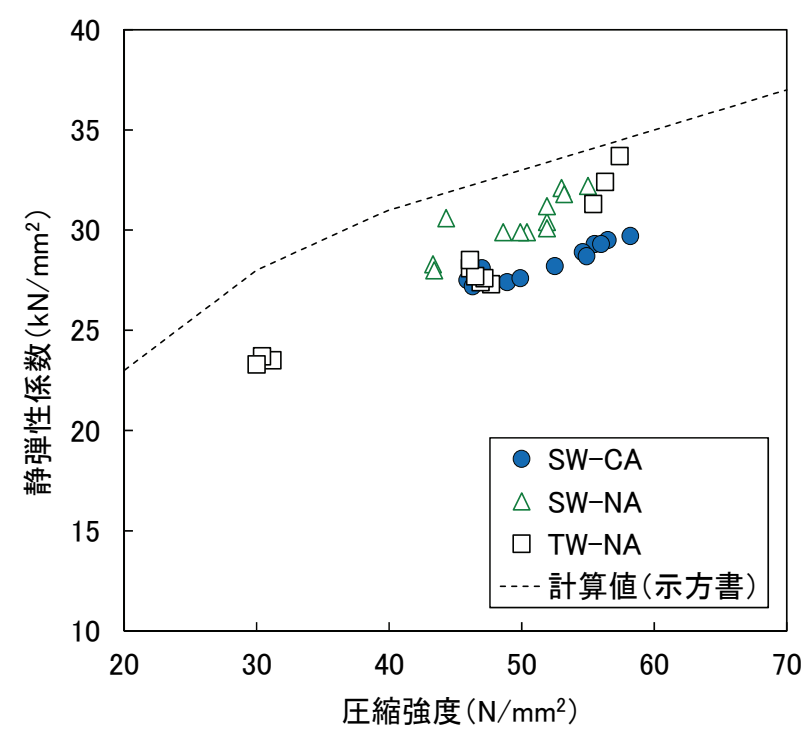

図-11 圧縮強度と静弾性係数の関係

方書【設計編】から算定した值である.図より，ばらつ きはあるものの, 同じ圧縮強度における静弾性係数は, 普通骨材を用いた配合（TW-NA，SW-NA）に比へ，珊 瑚骨材を用いた配合（SW-CA）の方が相対的にやや小 さくなる傾向が認められた。これは，骨材自体の弾性係 数の違いが影響したためと推察される.

\section{4. コンクリートの収縮特性}

\section{(1) 実験概要}

\section{a) 配合および使用材料}

コンクリートは，表-3 の環境温度が $20^{\circ} \mathrm{C}$ 配合のうち， 海水と普通骨材の配合（SW-NA）の単位粗骨材容積を 海水と珊瑚骨材の配合（SW-CA）と同量となるように 修正した表-7 の配合を用いた。 なお，使用材料は表-4 と同じである.

\section{b) 試験項目および方法}

コンクリートの試験項目の一覧を表-8 に示す. 長 さ・質量変化率の試験体は，材齢 1 日まで $20^{\circ} \mathrm{C}$ 環境 下で封緘養生を行った後に脱型し, 標準水中養生を行っ た. なお，長さ・質量変化率の試験体は材龄 7 日に基長 を測定し，ダイヤルゲージ法により測定を行った。また， ひび割れ抵抗性を確認するための拘束試験の供試体は, 型枠を脱型する材齢 7 日まで上面の湿布養生を行い，脱 型後, 拘束形鋼に設置したワイヤストレインゲージによ り，コンクリートに生じるひずみを計測した。

\section{(2) 実験結果および考察}

a) 自己収縮

コンクリートのひずみの経時変化を図-12 に示す．普 
表-7 コンクリートの配合

\begin{tabular}{|c|c|c|c|c|c|c|c|c|c|c|c|c|}
\hline \multirow[b]{2}{*}{ No. } & \multirow[b]{2}{*}{ 記号 } & \multirow[b]{2}{*}{$\begin{array}{l}\text { W/C } \\
(\%) \\
\end{array}$} & \multirow[b]{2}{*}{$\begin{array}{l}\mathrm{s} / \mathrm{a} \\
(\%)\end{array}$} & \multirow{2}{*}{$\begin{array}{c}\text { 単位粗骨 } \\
\text { 材容積 } \\
\left(\mathrm{m}^{3} / \mathrm{m}^{3}\right)\end{array}$} & \multicolumn{7}{|c|}{ 単位量 $\left(\mathrm{kg} / \mathrm{m}^{3}\right)$} & \multirow{2}{*}{$\frac{\text { 混和斉 }(\mathrm{C} \times \%)}{\text { Ad1 }}$} \\
\hline & & & & & $\begin{array}{l}\text { 上水 } \\
\mathrm{TW}\end{array}$ & $\begin{array}{c}\text { 海水 } \\
\text { SW }\end{array}$ & $\begin{array}{c}\text { セメント } \\
\mathrm{C}\end{array}$ & \begin{tabular}{|c|} 
普通 \\
細骨材 \\
NS
\end{tabular} & \begin{tabular}{|c|c|} 
珊瑚 \\
細骨材 \\
CS
\end{tabular} & \begin{tabular}{|c} 
普通 \\
粗骨材 \\
NG
\end{tabular} & 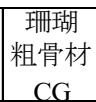 & \\
\hline 1 & $-\mathrm{CA}$ & & 50.8 & & - & 185 & 411 & - & 845 & - & 756 & 1.25 \\
\hline 2 & SW-NA & & 52.0 & & - & 175 & 389 & 880 & - & 828 & - & 1.10 \\
\hline 3 & TW-NA & & \begin{tabular}{|l|}
49.7 \\
\end{tabular} & 0.330 & 175 & - & 389 & 848 & - & 878 & - & 1.45 \\
\hline
\end{tabular}

表-8 試験項目および方法

\begin{tabular}{|c|c|c|}
\hline 試験項目 & 試験方法 & 試験条件等 \\
\hline 自己収縮 & $\begin{array}{l}\text { 埋込型ひず } \\
\text { み計による }\end{array}$ & $\begin{array}{l}\text { 自己収縮研究委員会報告書(JCI) の試験方法 } \\
\text { に準拠 }\end{array}$ \\
\hline $\begin{array}{l}\text { 長さ・質量 } \\
\text { 変化率 }\end{array}$ & JIS A 1129 & $\begin{array}{l}\text { 基長・乾燥開始材齢：7日 } \\
\text { 養生条件：標準水中養生（材齢1～7日） }\end{array}$ \\
\hline $\begin{array}{l}\text { 乾燥収縮 } \\
\text { ひずみ(拘束) }\end{array}$ & JIS A 1151 & 試験体数：3体/配合 \\
\hline
\end{tabular}

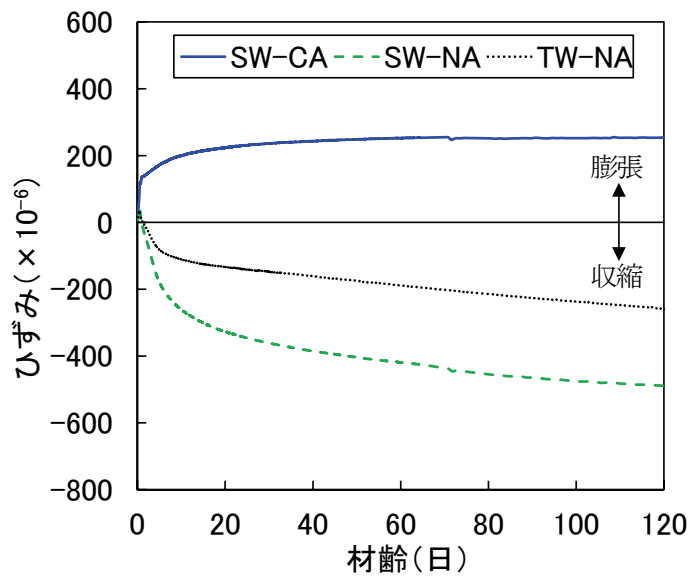

図-12 自己収縮ひずみの経時変化

通骨材を用いた場合，海水配合（SW-NA）のひずみが， 上水道水配合（TW-NA）のものに比べて $200\left(\times 10^{-6}\right)$ 程度収縮側に増加する傾向を示した。これは，練混ぜ水 に海水を使用するとセメントの水和反応が促進され，セ メントペーストの自己乾燥に伴う体積減少が大きくなっ たためと推察される。一方，珊瑚骨材を用いた配合

（SW-CA）では，同じ海水で練混ぜを行ったにもかか わらず，ひずみの值が正となる，すなわち膨張側を推移 する傾向を示した． 既往の研究 ${ }^{13)-15)}$ によると，珊瑚骨材 と同様に内部の空隙が多く, 吸水率の大きい人工軽量骨 材を用いたコンクリートでは，自己収縮ひずみが膨張側 を推移することがある。これは，骨材内部の空隙を満た 寸水が，セメントの水和が進行する過程で徐々にセメン トペーストに滲多出すという内部養生の効果により，ペ 一ストの湿度が相対的に高まることが一因とも考察され ている ${ }^{15}$.

\section{b) 乾燥収縮}

コンクリートの長さ変化率の経時変化を図-13 に，質 量変化率と長さ変化率の関係を図-14 に示寸。これらの 図より，珊瑚骨材を用いた配合（SW-CA）は，普通骨 材を用いた配合（SW-NA，TW-NA）に比べて質量変化 率は大きくなるものの, 長さ変化率は小さくなり, 乾燥

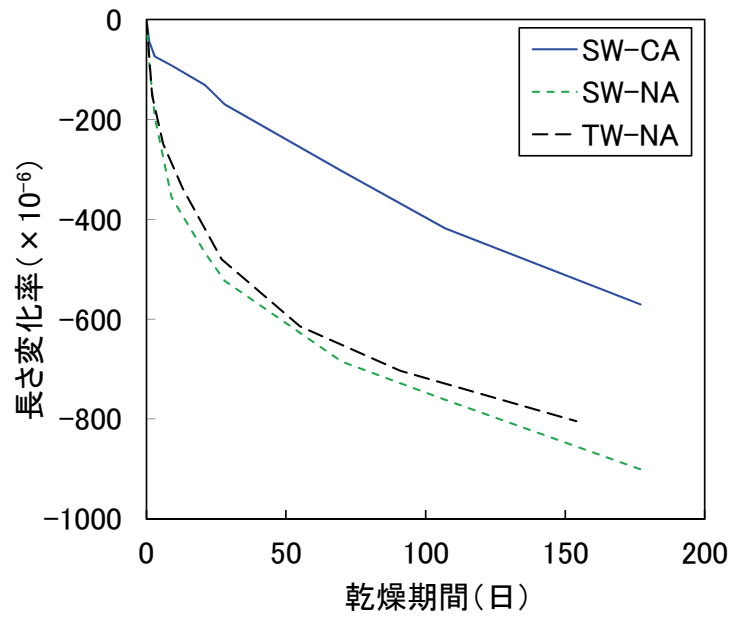

図-13 長さ変化率の経時変化

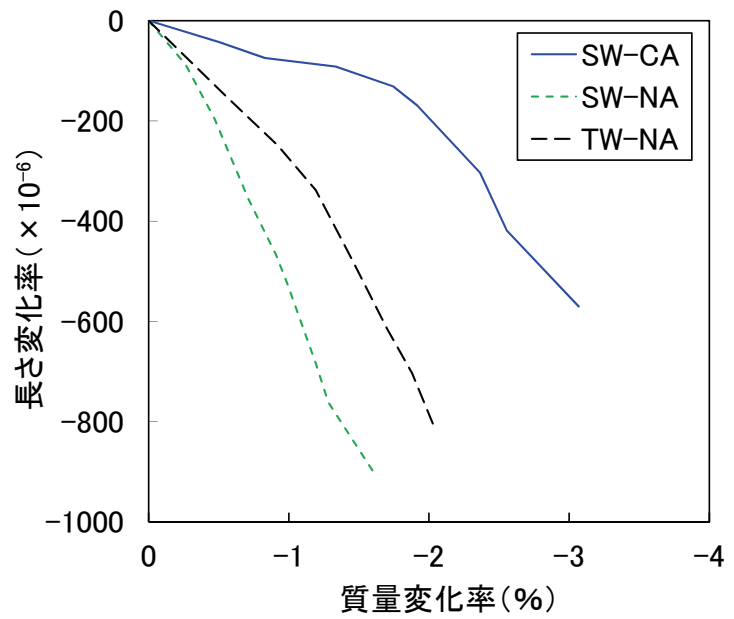

図-14 質量変化率と長さ変化率の関係

収縮が抑制されることが示唆された．これは，前述の自 己収縮の影響も含まれると考えられるが，既往の研究 ${ }^{15}$ によれば，骨材自体の収縮特性の違いが起因した可能性 もある.

\section{c) ひび割れ抵抗性}

拘束を受けたコンクリートの乾燥に伴う収縮応力の経 時変化を図-15 に示寸. なお, 収縮応力は, ワイヤスト レインゲージにより計測した拘束形鋼のひずタから，コ ンクリートと形鋼にはたらく力のつりあい関係をもとに 算定した值である. 普通骨材を用いた場合, 上水道水配 合（TW-NA）は乾燥開始から 3〜8 日程度で，海水配合 （SW-NA）は 3〜15 日程度でそれぞれひび割れが発生 （収縮応力が解放されて $0 \mathrm{~N} / \mathrm{mm}^{2}$ となった時点）し，後 


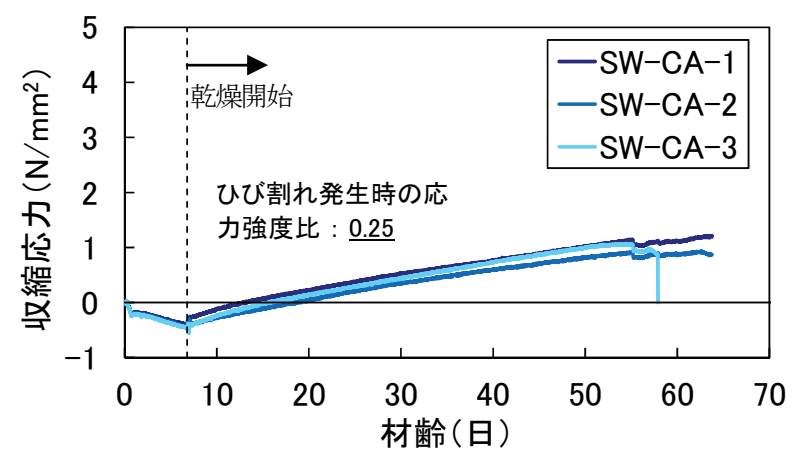

(a) SW-CA

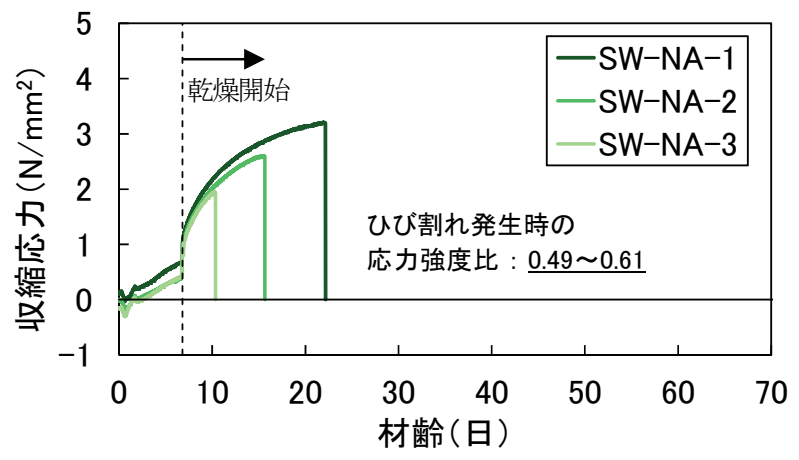

(b) SW-NA

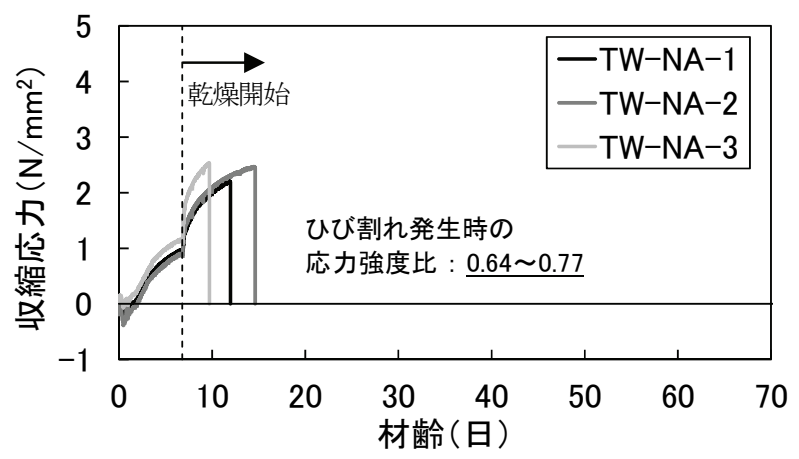

(c) TW-NA

図-15 材齢と収縮応力の関係

者のほうが，若干ひび割れ抵抗性が向上する結果となっ た。一方，珊瑚骨材を用いた配合（SW-CA）は，他の 配合に比べてコンクリートに作用する収縮応力が小さく, 乾燥開始から 51 日後，3供試体のうち 1 体にひび割れが 認められた.この収縮応力の低下については，前述した 自己収縮や乾燥収縮が小さくなる特性からも想定できる 結果といえる.

\section{d）コンクリートの体積変化に関する考察}

以上のように，骨材の違いによってコンクリートの体 積変化の傾向が大きく異なることが明らかとなった，そ こで，本研究ではその要因を推定するため，粗骨材単体 の体積変化の挙動と，コンクリート中の骨材近傍の組織 について確認を行った.

粗骨材の体積変化は, 山田らの研究 ${ }^{10}$ 参考に, 径が $20 \mathrm{~mm}$ 程度, 吸水率が平均值程度の粗骨材を対象に, 珊 瑚粗骨材と普通粗骨材で比較した．写真-3に示すとお

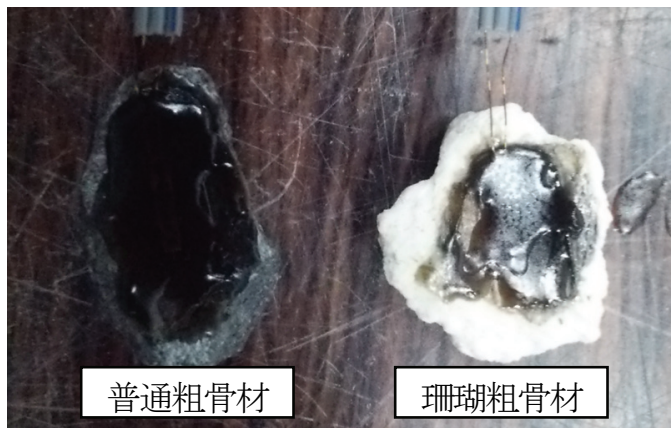

写真-3 粗骨材への攵ージ添付状況

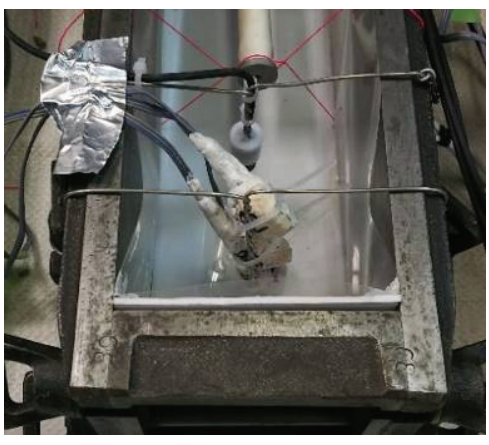

写真-4 粗骨材の設置状況

り，粗骨材の一部を研磨した後，防水処理を施したワイ ヤストレインゲージを設置して粗骨材単体のひずみを測 定した。 これらの粗骨材は，24 時間以上吸水させて表 乾状態にした後， $20^{\circ} \mathrm{C} 60 \%$ R.H.の雰囲気で乾燥させたも のと，自己収縮供試体と同じ方法で作製したコンクリー ト中に，写真-4のように設置したものの 2 ケースとした. なお，コンクリートの配合は表-7 の No.1 および No.2 を 用いた。

乾燥環境およびコンクリート中における粗骨材のひず みの経時変化を図-16 に示す．珊瑚粗骨材の収縮ひずみ は，乾燥環境，コンクリート中のいずれのケースでも普 通粗骨材に比べて小さくなる傾向を示し，コンクリート 中ではやや膨張側を推移した。 これらの傾向は，前述し たコンクリートの自己収縮や乾燥収縮の結果に符合する ものであり，コンクリートの体積変化の差異は，粗骨材 の体積変化の違いが影響していたものと推察される。す なわち, 珊瑚粗骨材の体積変化量は普通粗骨材に比べて 小さいため，それを用いたコンクリートの体積変化も小 さくなるようである。コンクリート中で珊瑚粗骨材が膨 張するメカニズムは明らかでないが，例えば，前述のよ うに，人工軽量骨材と同じようなインクボトル空隙を有 する細骨材の内部養生効果により，モルタルの湿度が相 対的に増加し，この湿度増加が粗骨材の体積変化に影響 を与えた可能性が考えられる．なお，上記のコンクリー 卜の供試体について, 試験終了後（材齢約 15 週）に内 部のコンクリート片を採取して含水率を測定した結果, 珊瑚骨材を用いた場合が $6.9 \%$ ，普通骨材を用いた場合 


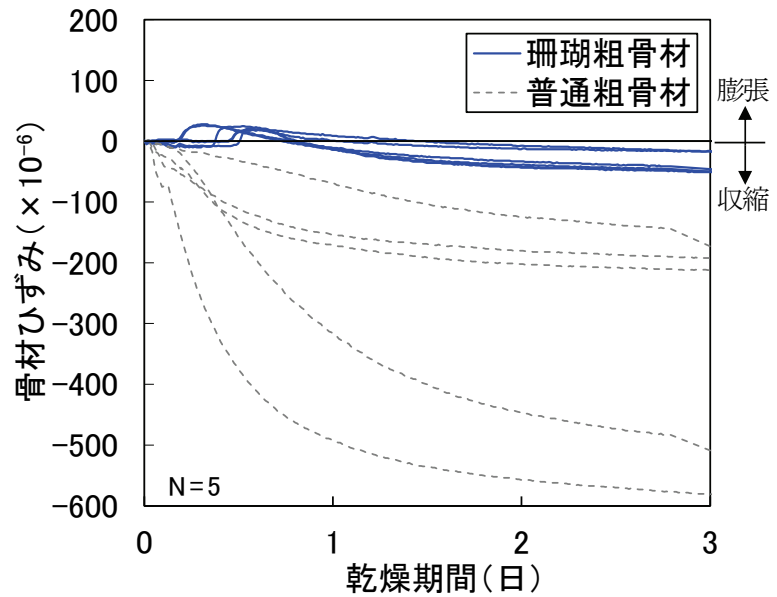

(a) 乾燥環境

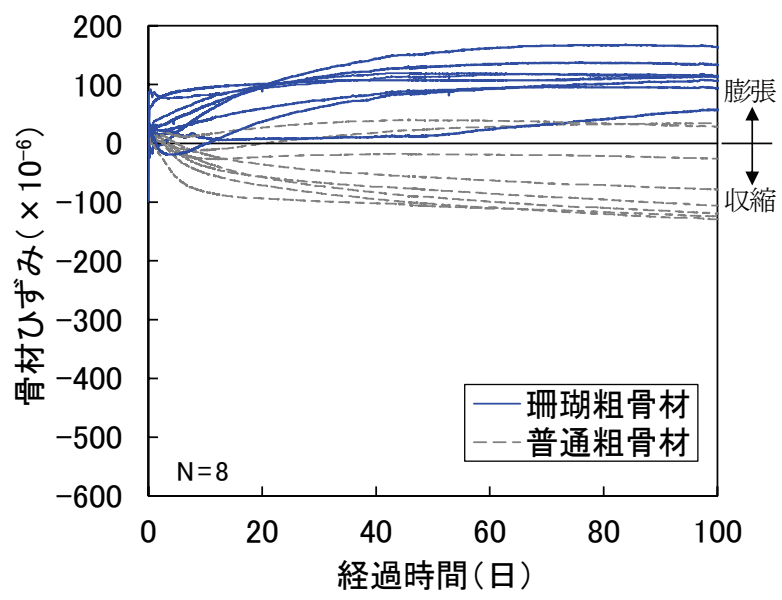

(b) コンクリート中

図-16 骨材ひずみの経時変化

が 5.0 \%であり，珊瑚骨材を用いたコンクリートのほう が高かつた.

また，上記供試体中の骨材近傍の組織について，走査 型電子顕微鏡（SEM）による観察を行った. 粗骨材と粗 骨材の観察像を，それぞれ図-17，図-18 に示す。珊瑚粗 骨材の一部に水の出入り等に起因した粗な部分が見受け られたものの，全体的には骨材界面や之の近傍の組織に 明確な違いは見られず，骨材の種類の違いによる影響は 認められなかった。

\section{5. コンクリートの熱的性質}

\section{(1) 実験概要}

\section{a) 配合および使用材料}

コンクリートの配合は，表-7 の No.1 と 2 の配合を用 いた.

\section{b) 試験項目および方法}

コンクリートの熱的性質を把握するため, 熱膨張係数, 熱伝導率，熱拡散率および断熱温度上昇量を確認した.
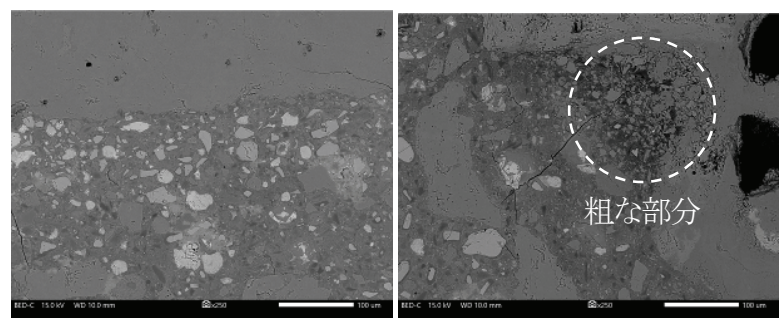

(a) 珊瑚粗骨材 $($ 倍率 : $\times 250)$
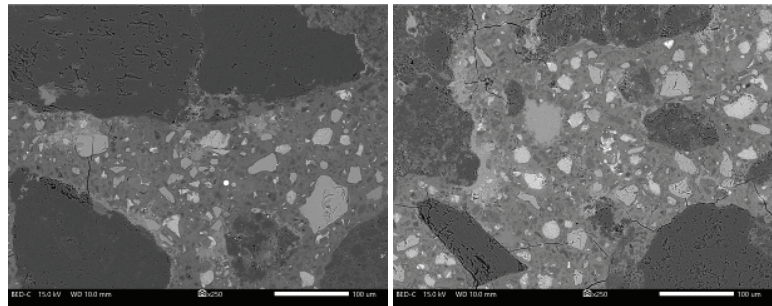

(b) 普通粗骨材 $($ 倍率 : $\times 250)$

図-17 粗骨材の観察像
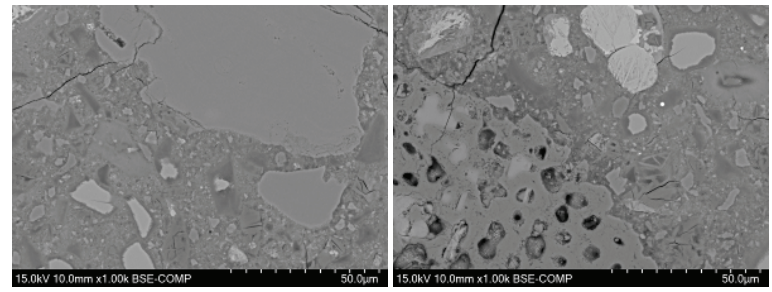

(a) 珊瑚細骨材 (倍率 : $\times 1000)$
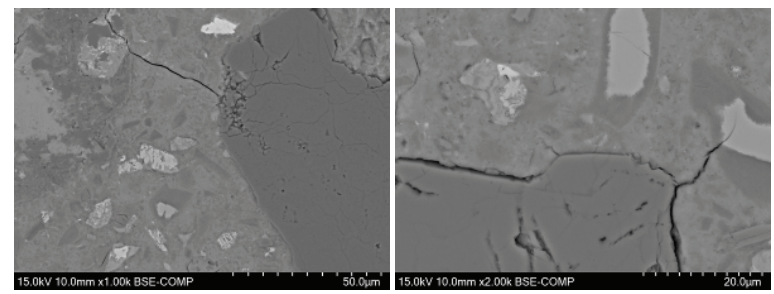

(b) 普通細骨材 $($ 倍率 : $\times 1000)$

図-18 細骨材の観察像

熱膨張係数は， $\phi 100 \times 200 \mathrm{~mm}$ のコンクリートの中心部 に埋込型ひずみ計を設置して測定した。 コンクリートの 打込み後, 雰囲気温度を $20^{\circ} \mathrm{C} \rightarrow 60^{\circ} \mathrm{C} \rightarrow 20^{\circ} \mathrm{C}$ と変化させ, この温度上昇・降下サイクルを最大 4 サイクルまで与え た. なお，上昇・降下はそれぞれ 1.5 日かけて行い, $60^{\circ} \mathrm{C}$ たは $20^{\circ} \mathrm{C}$ 達する毎に 1.0 日の恒温期間を設けた. 試験体周囲の温度履歴を図-19 に示す．熱伝導率は，100 $\times 100 \times 400 \mathrm{~mm}$ のコンクリート供験体に加熱線の付いた プローブを押しあて，この時の供試体の温度上昇と時間 の関係を演算して, 熱伝導率を算出した. 1 供試体あた り 10 箇所の測定を行い，その平均值を熱伝導率とした. 熱伝導率の測定状況を写真-5に示す。熱拡散率は，材 齢 28 日まで $\phi 100 \times 200 \mathrm{~mm}$ の円柱供試体を標準養生し た後, $60^{\circ} \mathrm{C}$ の恒温水槽に移し, 供試体中心温度が水温と 同一になり供試体内部に温度勾配が生じない状態になっ た時点で，直ちに $20^{\circ} \mathrm{C}$ の定常冷水中に移動し，供試体 


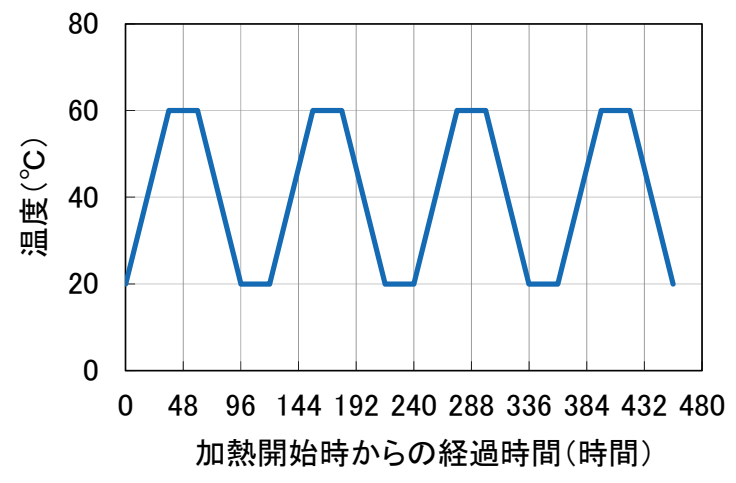

図-19 熱膨張係数試験の温度履歴

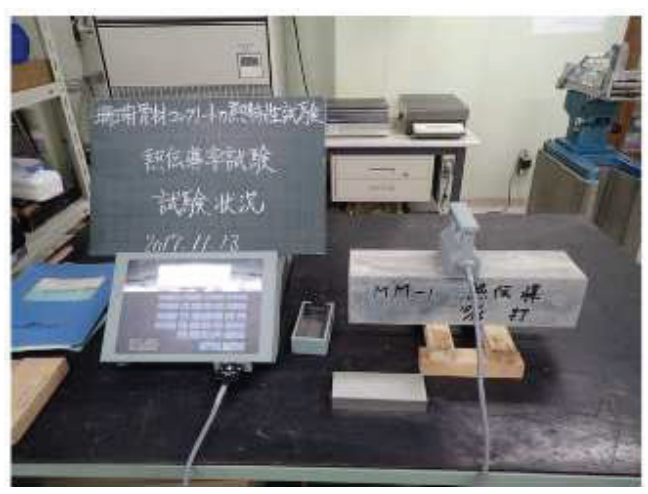

写真-5 熱伝導率の測定状況

中心温度及び水槽温度を 2 分間隔で 60 分間測定した. 測定時間毎に熱拡散率を求め，測定時間 20～60 分の測 定值の平均值を熱拡散率とした。 断熱温度上昇量試験に ついては，試験機には空気循環式試験機を使用し，コン クリートを円筒形容器 (容積約 $55 \ell$ l) に打ち込んだ後, ヒータを制御することでコンクリートを擬似的な断熱状 態に保ち, コンクリート中心部の上昇温度が定常状態に なるまで測定を行った。

\section{（2）実験結果および考察}

\section{a) 熱膨張係数}

各配合のコンクリート温度とひずみの関係を求め, そ の上昇・下降勾配から算出した熱膨張係数を表-9, 図20 に示す.なお，熱膨張係数の算出にあたっては，温 度変化が不安定な期間の影響を除外するために，25ㅇ

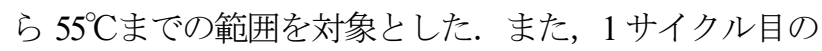
温度上昇時から算出した值は，明らかにコンクリート自 体が硬化しておらず，埋込型ひずみ計とコンクリートが 一体化していない等の影響が含まれていると考えられる ため, 本研究では，值が概ね安定した 2 サイクル目以降 の結果により評価した。普通骨材の配合（SW-NA）の 熱膨張係数は $14 \mu{ }^{\mathrm{C}}$ 程度となり，コンクリート標準示 方書等に示される值（高炉 B 種 : $12 \mu \mathrm{C}$ ）に比べてやや 大きな值を示した。一方，珊瑚骨材の配合（SW-CA） は, SW-NA に比べて值が大幅に小さくなり, $6 \mu{ }^{\rho} \mathrm{C}$ 程度
表-9 熱膨張係数

\begin{tabular}{c|c|c|c|c|c|c}
\multicolumn{4}{c}{} & \multicolumn{2}{c}{ 表-9 熱膨張係数 } & \multicolumn{2}{c}{ 単位 : $\mu^{P} \mathrm{C}$} \\
\hline \multirow{2}{*}{ サイクル } & \multicolumn{2}{c}{ SW-CA } & \multicolumn{2}{c}{ SW-NA } & \multicolumn{2}{c}{ TW-NA } \\
\cline { 2 - 7 } & 上昇時 & 降下時 & 上昇時 & 降下時 & 上昇時 & 降下時 \\
\hline \hline 1 & 9.4 & 5.3 & 2.0 & 12.3 & 3.5 & 10.0 \\
\hline 2 & 5.3 & 5.5 & 12.7 & 13.9 & 9.7 & 11.4 \\
\hline 3 & 5.4 & 5.7 & 13.9 & 14.5 & 10.8 & 12.2 \\
\hline 4 & 5.5 & 5.9 & 14.2 & 14.6 & 11.6 & - \\
\hline
\end{tabular}

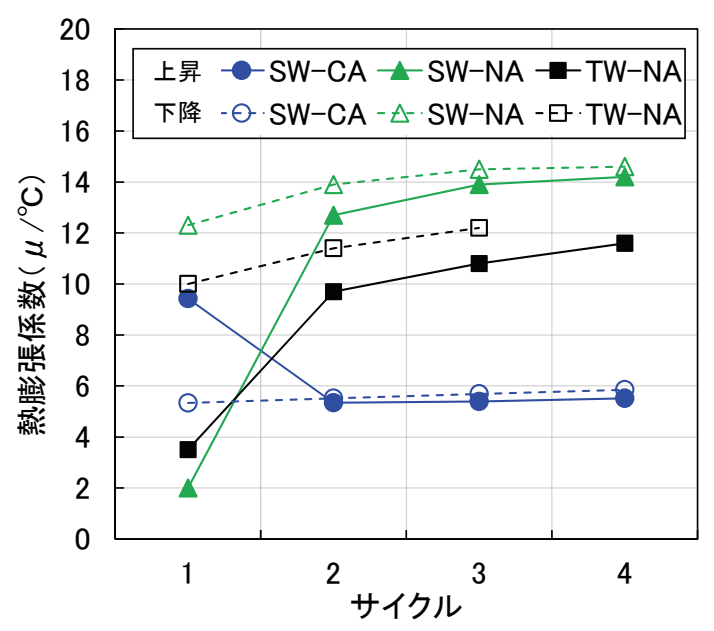

図-20 熱膨張係数の推移

表-10 試験結果一覧

\begin{tabular}{l|c|c}
\hline \multicolumn{1}{c|}{ 試験項目 } & SW-CA & SW-NA \\
\hline \hline 熱拡散率 $(\mathrm{m} / \mathrm{h})$ & 0.00159 & - \\
\hline 熱伝導率 $(\mathrm{W} / \mathrm{mK})$ & 1.29 & $2.7^{※}$ \\
\hline 密度 $\left(\mathrm{g} / \mathrm{cm}^{3}\right)$ & 2.197 & 2.282 \\
\hline 比熱 $(\mathrm{kJ} / \mathrm{kgK})$ & 1.3 & $1.16^{\%}$ \\
\hline \multirow{2}{*}{ 断熱温度上昇量 } & $54.4(1-\exp (-1.08 \mathrm{t}))$ & $53.8(1-\exp (-1.18 \mathrm{t}))$ \\
\cline { 2 - 4 } & $\mathrm{C}=411 \mathrm{~kg} / \mathrm{m}^{3}$ & $\mathrm{C}=386 \mathrm{~kg} / \mathrm{m}^{3}$ \\
\hline \multicolumn{2}{|c}{} & ※コンクリート標準示方書より
\end{tabular}

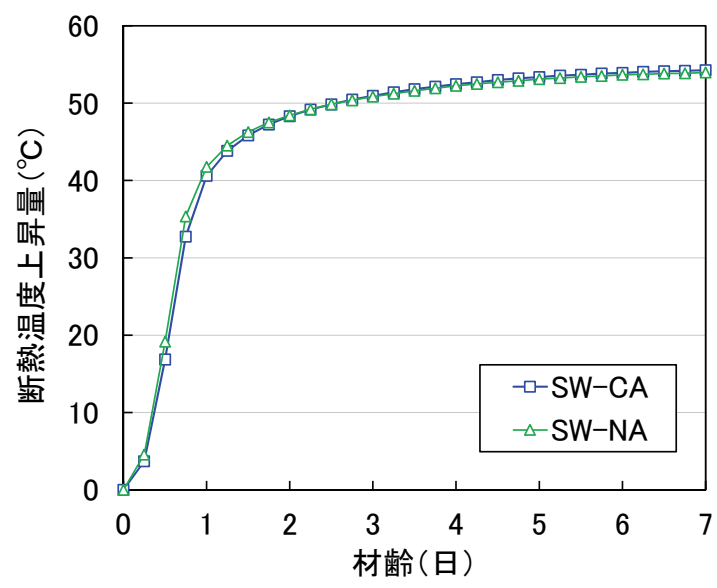

図-21 断熱温度上昇量の経時変化

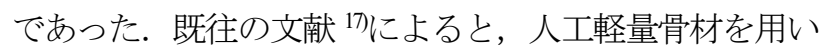
たコンクリートの熱膨張係数は普通骨材のコンクリート に比べて小さく，6〜9 $\mu$ Cといわれている. 本研究で得 られた珊瑚骨材の值も人工軽量骨材の值と概ね同等の結 果であり，骨材内部の空隙構造が影響を及ぼしたものと 推察される. 
表-11 コンクリート・モルタルの配合

\begin{tabular}{|c|c|c|c|c|c|c|c|c|c|c|c|c|c|c|c|c|c|}
\hline \multirow[b]{2}{*}{ 記号※1 } & \multirow[b]{2}{*}{$\begin{array}{c}\text { フロー } \\
\text { スランプ } \\
(\mathrm{mm}, \mathrm{cm})\end{array}$} & \multirow[b]{2}{*}{$\begin{array}{c}\text { 空気量 } \\
(\%) \\
\end{array}$} & \multirow[b]{2}{*}{$\begin{array}{l}\mathrm{W} / \mathrm{C} \\
(\%) \\
\end{array}$} & \multirow[b]{2}{*}{$\begin{array}{l}\text { s/a } \\
(\%) \\
\end{array}$} & \multirow[b]{2}{*}{$\begin{array}{c}\text { 粗骨材 } \\
\text { 最大寸法 } \\
(\mathrm{mm})\end{array}$} & \multirow{2}{*}{$\begin{array}{c}\text { 単位粗骨 } \\
\text { 材容積 } \\
\left(\mathrm{m}^{3} / \mathrm{m}^{3}\right)\end{array}$} & \multicolumn{6}{|c|}{ 単位量 $\left(\mathrm{kg} / \mathrm{m}^{3}\right)$} & \multicolumn{3}{|c|}{ 混和剂 $(\mathrm{C} \times \%)$} & \multirow{2}{*}{\begin{tabular}{|c|} 
摩耗試 \\
験回数 \\
$\mathrm{N}$
\end{tabular}} & \multirow{2}{*}{ 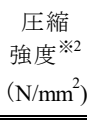 } \\
\hline & & & & & & & $\begin{array}{c}\text { 海水 } \\
\text { SW }\end{array}$ & \begin{tabular}{|c|} 
セメント \\
C
\end{tabular} & \begin{tabular}{|c|} 
普通 \\
細骨材 \\
NS \\
\end{tabular} & \begin{tabular}{|c|} 
姍瑚 \\
細骨材 \\
CS \\
\end{tabular} & \begin{tabular}{|c|} 
普通 \\
粗骨材 \\
NG \\
\end{tabular} & \begin{tabular}{|c|} 
姍瑚 \\
粗骨材 \\
CG \\
\end{tabular} & Ad1 & Ad4 & Ad5 & & \\
\hline 45-CA-315 & \multirow{2}{*}{$600 \pm 50$} & \multirow{12}{*}{$4.5 \pm 1.5$} & 45 & 50.8 & 25 & 0.315 & 185 & 4411 & & 845 & & 756 & 1.4 & & & 2 & 56.5 \\
\hline 45-NA-315 & & & 45 & 52.0 & 20 & 0.315 & 175 & 389 & 880 & & 838 & & 1.1 & & & 2 & 51.5 \\
\hline 45-CA-360 & \multirow{10}{*}{$15 \pm 2.5$} & & 45 & 45.1 & 25 & 0.360 & 175 & 389 & & 770 & & 864 & & 0.8 & & 1 & 50.2 \\
\hline 45-NA-360 & & & 45 & 45.1 & 20 & 0.360 & 175 & 389 & 764 & & 958 & & & 0.7 & & 2 & 48.3 \\
\hline 50-CA-315 & & & 50 & 52.9 & 25 & 0.315 & 175 & 350 & & 920 & & 756 & & 0.9 & & 1 & 46.2 \\
\hline 50-CA-360 & & & 50 & 46.2 & 25 & 0.360 & 175 & 350 & & 803 & & 864 & & 1.0 & & 1 & 52.6 \\
\hline 50-NA-315 & & & 50 & 52.9 & 20 & 0.315 & 175 & 350 & 913 & & 838 & & & 0.7 & & 1 & 45.2 \\
\hline 50-NA-360 & & & 50 & 46.2 & 20 & 0.360 & 175 & 350 & 797 & & 958 & & & 0.4 & & 1 & 45.3 \\
\hline 55-CA-315 & & & 55 & 53.6 & 25 & 0.315 & 175 & 318 & & 946 & & 756 & & & 1.7 & 2 & 44.8 \\
\hline 55-CA-360 & & & 55 & 47.0 & 25 & 0.360 & 175 & 318 & & 829 & & 864 & & & 1.1 & 3 & 42.5 \\
\hline 55-NA-315 & & & 55 & 53.6 & 20 & 0.315 & 175 & 318 & 939 & & 838 & & & & 1.2 & 1 & 37.0 \\
\hline 55-NA-360 & & & 55 & 47.0 & 20 & 0.360 & 175 & 318 & 823 & & 958 & & & & 1.0 & 3 & 40.0 \\
\hline 45-CA-M & \multirow{4}{*}{$\begin{array}{c}\text { モルタル } \\
\text { フロー } \\
200 \pm 20\end{array}$} & \multirow{4}{*}{ - } & 45 & \multicolumn{9}{|c|}{ 45-CA-315から粗骨材を除いた配合 } & 0.9 & & & 1 & 65.3 \\
\hline 45-NA-M & & & 45 & \multicolumn{9}{|c|}{ 45-NA-315から粗骨材を除いた配合 } & 0.6 & & & 1 & 58.4 \\
\hline 55-CA-M & & & 55 & \multicolumn{9}{|c|}{ 55-CA-315から粗骨材を除いた配合 } & & & 1.7 & 1 & 49.5 \\
\hline 55-NA-M & & & 55 & \multicolumn{9}{|c|}{ 55-NA-315から粗骨材を除いた配合 } & & & 1.0 & 1 & 35.0 \\
\hline
\end{tabular}

※1 W/C-骨材種類-単位粗骨材容積, $\mathrm{M}$ ：モルタル ※2 摩耗試験回数が複数の場合は平均值を示す

\section{b) 熱伝導率，熱拡散率および比熱}

各試験の測定結果を表-10 に示す。珊瑚骨材の配合 （SW-CA）は，コンクリート標準示方書に示されてい る普通骨材のコンクリートに比べて熱が伝わりにくい特 徵を有するようである.

\section{c) 断熱温度上昇量}

コンクリートの断熱温度上昇量の経時変化を図-21 に 示す．珊瑚骨材の配合（SW-CA）のほうが単位セメン トが多いため，温度上昇量の大きくなることが想定され たが，本研究の範囲では，珊瑚骨材の配合（SW-CA） と普通骨材の配合（SW-NA）の温度履歴はほぼ同等で あった。一般的に，コンクリートの温度上昇量は熱容量 （比熱と質量の積）に反比例するといわれている ${ }^{17}$. 表 -10 に示寸とおり，SW-CA は SW-NA に比べて比熱が大 きく熱容量が大きかったため，これに起因する温度上昇 量の低下が，単位セメント量の増加に伴う温度上昇量の 増加と相殺し, 結果的に断熱温度上昇量が同等になった ものと推察される.

以上のように，珊瑚骨材を用いたコンクリートは，普 通骨材を用いたコンクリートと同等の断熱温度上昇特性 を有し，さらに熱膨張係数が小さくなるため，マスコン クリートに活用寸る場合は温度応力が低減し，有利にな るものと考えられる.

\section{6. コンクリートの耐摩耗性}

\section{（1） 実験概要}

珊瑚骨材を用いたコンクリートの耐摩耗性を検証する ため，表-11 に示す全 16 種類の配合を用いて検討を行っ た．本章では，前章までの自己充填型コンクリート（表 -11 の 45-CA-315，45-NA-315）の耐摩耗性を評価するに あたり，水セメント比や単位粗骨材容積の妥当性を検証

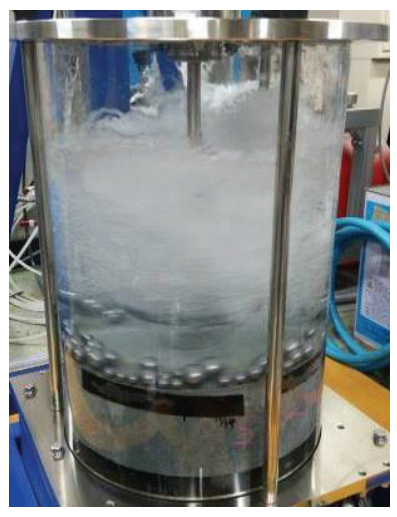

写真-6 流体エロージョン試験

すべく，水セメント比を $45 ， 50 ， 55 \%$ の 3 水準，単位粗 骨材容積を $0.315,0.360 \mathrm{~m}^{3} / \mathrm{m}^{3}$ の 2 水準とし，それぞれ珊 瑚骨材と普通骨材を用いて比較した。 また，水セメント 比が $45 ， 55 \%$ の一部の配合においては，粗骨材を除い たモルタルについても検討した。 コンクリートの材料は, 表-4 の材料に加えて, 混和剂に高性能 $\mathrm{AE}$ 減水剂 (Ad4) や $\mathrm{AE}$ 減水剂（Ad5）も使用した。コンクリート の耐摩耗性は，流体エロージョン試験（ASTM C1138） に累積すり減り係数により評価した. 流体エロージョン 試験とは，写真-6 に示寸ような円筒状の容器の中に $\phi$ $300 \times 110 \mathrm{~mm}$ の供試体を設置し, 砂利を模擬した直径 12.6 25.3 mm の計 70 個の鋼球を水中で回転させ，供試 体上面の単位面積あたりのすり減り量（以下，すり減り 係数と称す) を最大 72 時間まで測定するものである.

\section{(2) 実験結果および考察}

表-11 に示寸とおり, 同一水セメント比のコンクリー ト・モルタルの圧縮強度は，珊瑚骨材を用いた場合のほ うが普通骨材に比べて大きくなる傾向を示し，モルタル のほうが顕著であった．これは，骨材表面の形状や水分 移動等の影響による界面の付着性能が起因した可能性も 考えられるが明らかではない。 


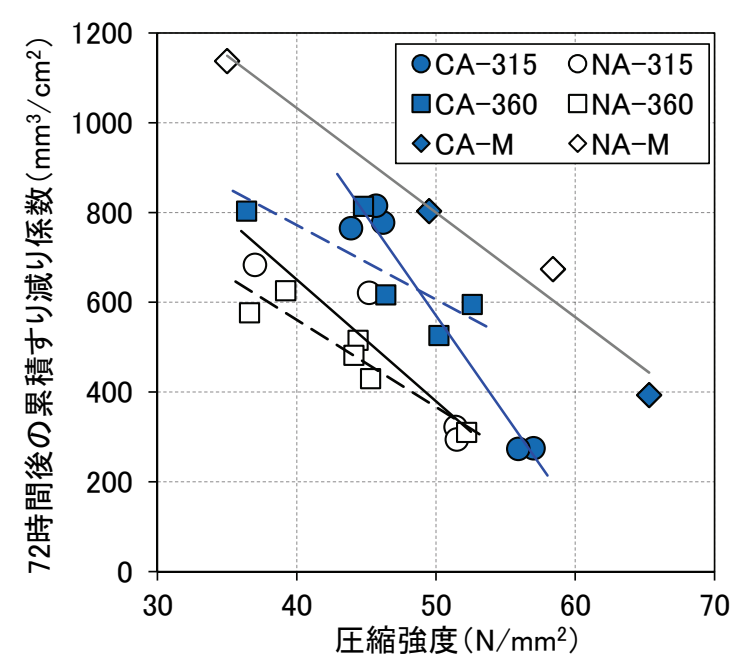

図-22 圧縮強度と累積すり減り係数の関係

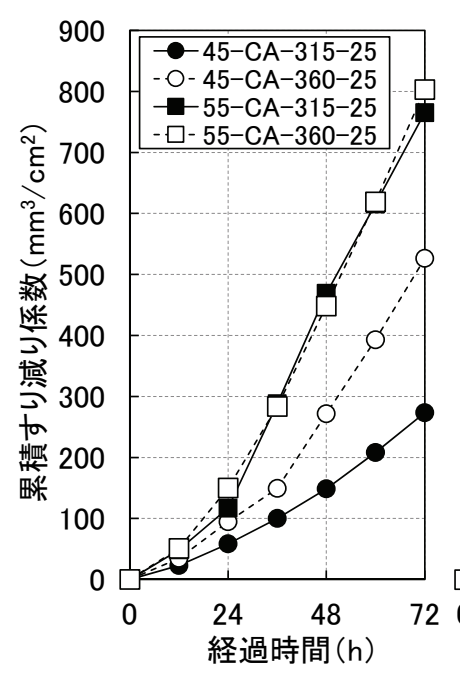

(a) 珊瑚骨材

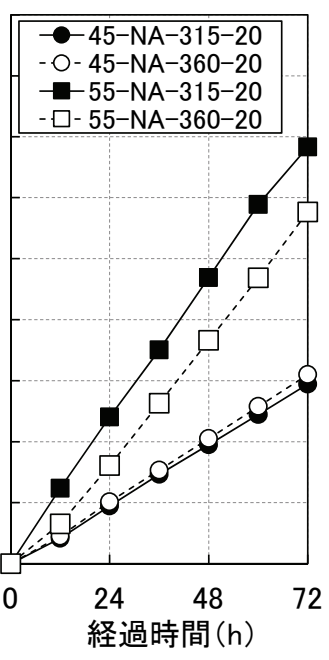

(b) 普通骨材
図-23 累積すり減り係数の経時変化

コンクリートの圧縮強度と 72 時間後の累積すり減り 係数の関係を図-22 に示す.モルタル $(\diamond \triangleright$ 印) の試験 結果に着目すると，前述したとおり，同じ配合でも使用 する骨材の種類によって強度差が生じたものの，累積す り減り係数との関係では骨材の種類に因らず高い相関が 認められた. 一方, コンクリートでは, 全体的にモルタ ルより累積すり減り係数が小さくなる，すなわち耐摩耗 性が向上する傾向を示したが，骨材の種類や単位粗骨材 容積によって圧縮強度と累積すり減り係数の関係が異な った. コンクリートの而摩耗性は, 珊瑚骨材（CA）の ほうが普通骨材（NA）に比べて低くなり, 珊瑚骨材の 脆さが影響する結果となった。コンクリート強度が比較 的小さい領域においては，既往の知見 ${ }^{18)}$ と同様に，単位 粗骨材容積の増加により而摩耗性の向上が見られたもの の, 圧縮強度の増加に伴いその差は小さくなった. 特に 珊瑚骨材の場合は，脆弱な粗骨材の影響が顕著になるよ うである。

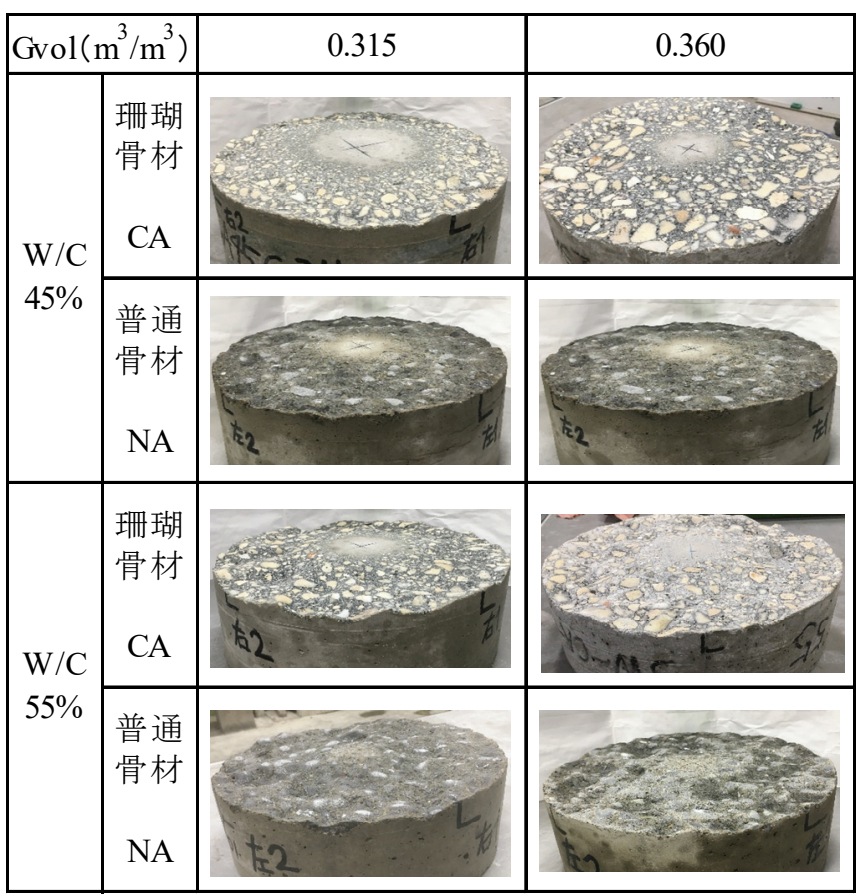

写真-7 試験終了後の摩耗状況

セメント比 45，55\%の配合における累積すり減り係 数の経時変化を図-23に, 試験終了後（72 時間後）の摩 耗状況を写真-7 に示す。普通骨材（NA）を用いた場合， いずれもほぼ直線的に累積すり減り係数が増加するのに 対し，珊瑚骨材（CA）を用いた場合には，水セメント 比が 55\%の配合 (ロ $\square$ 印) や $45 \%$ の単位粗骨材容積の 大きい配合 (○印) において，勾配が増加する変化点が 認められた. これは, 表面のモルタルが先行して摩耗し た後, 脆い珊瑚粗骨材が露出することで摩耗が加速した ためと推察され, 珊瑚骨材を用いたコンクリートの特徵 といえるが，同図に示すとおり，水セメント比や単位粗 骨材容積を小さく設定した本研究の自己充填型コンクリ 一ト $\left(\mathrm{W} / \mathrm{C}=45 \%\right.$, 単位粗骨材容積 $\left.0.315 \mathrm{~m}^{3} / \mathrm{m}^{3}\right)$ であれ ば，普通骨材を用いた場合と同程度の而摩耗性を確保で きると考えられる.

\section{7. 結論}

珊瑚由来の石灰石骨材の特徵とそれを用いた海水練り コンクリートの性質について検討した結果, 以下の事項 が明らかとなった。

(1) 珊瑚骨材は内部に多くの空隙を有する構造であり, 普通骨材に比べて吸水率が大きく，粒子間のばらつ きも大きい. また，その空隙構造は多様であり，人 工軽量骨材が有するようなインクボトル空隙も若干 確認された.

（2）上記のような品質の珊瑚骨材でも，適度な粘性を有 する本研究の自己充填型コンクリートへ適用する限 
りでは，所要の流動性や間隙通過性を確保できる. ただし，普通骨材を用いた場合に比べて加圧ブリー ディング試験における脱水量が少なくなり，骨材の 加圧吸水に伴うフレッシュ性状の変化が懸念される ため, コンクリートをポンプ圧送により打ち込む場 合は留意が必要である.

（3）珊瑚骨材を用いたコンクリートの強度発現性につい て，圧縮強度は練混ぜ水の種類の違いによる影響が 支配的であり，骨材の種類の違いによる影響は少な いが，静弾性係数は普通骨材を用いた場合に比べて やや小さくなる.

（4）練混ぜ水に海水を用いたコンクリートの自己収縮は, 上水道水を用いた場合に比べて増加するが，珊瑚骨 材を併用することで抑制できる．また，乾燥収縮も， 普通骨材を用いた場合に比べて小さくなり，拘束が 作用したときのひび割れは，発生するまでの期間が 長くなる. 姍瑚骨材を用いたコンクリートの収縮が 普通骨材に比べて小さくなる現象は，珊瑚骨材自体 の体積変化の差異が起因している可能性がある.

（5）練混ぜ水に海水を用いたコンクリートの熱膨張係数 は，上水道水を用いた場合に比べて若干大きくなる が，珊瑚骨材を併用することにより，人工軽量骨材 と同様に小さくなる．また，普通骨材を用いた場合 に比べて熱伝導率や熱拡散率は小さく，比熱は若干 大きくなるが，断熱温度上昇量については，本研究 の範囲では骨材の種類の違いによる明確な差は認め られなかった。

（6）珊瑚骨材を用いたコンクリートは，普通骨材を用い た場合に比べて耐摩耗性が低下寸るが，本研究の自 己充填型コンクリートの配合条件（W/C $=45 \%$ ，単 位粗骨材容積 $0.315 \mathrm{~m}^{3} / \mathrm{m}^{3}$ ) であれば，普通骨材を用 いた場合と同程度の性能を確保できる.

謝辞 : 本研究は，内閣官房総合海洋政策本部事務局及び 国土交通省総合政策局技術政策課により平成 26 年 4 月 に実施された「遠隔離島における産学官連携型の海洋関 連技術開発の公募」で採択されたものであり，国土交通 省関東地方整備局のご協力の下，早稲田大学，港湾空港 技術研究所, 五洋建設(株), 東亜建設工業(株), 東洋建 設(株)が共同で実施したものである．また，本研究の一 部で実施した流体エロージョン試験については，秋田大 学が保有する試験装置を用いて行ったものである.ここ に，試験の実施ならびに評価に際してご協力をいただい た徳重英信教授，高橋良輔准教授に謝意を表す.

\section{参考文献}

1) 酒井貴洋, 山路 徹, 清宮 理 : 海水および海砂を 用いた自己充填型コンクリートの実用化に関する基
礎的研究，土木学会論文集 E2（材料・コンクリート 構造），Vol.72，No.3，pp.196-213， 2016.

2) 鈴木哲郎, 清宮 理, 山路 徹, 竹中 寛, 酒井貴 洋, 田中亮一: 海水・海砂を用いた自己充填コンク リート用高性能 $\mathrm{AE}$ 減水剂(増粘剤一液タイプ)の開 発, 土木学会年次学術講演会講演概要集, Vol.67, No.5, pp.1181-1182, 2012.9

3) 竹中 寛, 酒井貴洋, 山路 徹, 清宮 理 : 海水お よび珊瑚骨材を用いた自己充填型コンクリートの基 本性能, コンクリート工学年次論文集, Vol.38, No.1, pp.1833-1838, 2016.6

4) 竹中 寛, 谷口 修, 山路 徹, 清宮 理 : 海水お よび珊瑚由来の石灰石骨材を用いた自己充填型コン クリートの諸特性, コンクリート工学年次論文集,

Vol.39, No.1, pp.1567-1572, 2017.6

5) 吉田 亮, 小幡雄一郎, 齊藤和秀, 梅原秀哲: イン クボトル関係を内包する人工骨材および天然骨材の 空隙構造に関する研究, コンクリート工学年次論文 集, Vol.32, No.1,pp.107-112, 2010.6

6) 土木学会 : コンクリートのポンプ施工指針, コンク リートライブラリー135, 2012.

7）馬場勇介，菅俣 匠，松倉隼人，矢口 稔：新規な 増粘剂一液型高性能 $\mathrm{AE}$ 減水剂を使用した低粘性高 流動コンクリートの基本特性, 土木学会年次学術講 演会講演概要集, Vol.66, No.5, pp.1143-1144, 2011.9

8) 山路 徹, 与那嶺 一秀, 川端 雄一郎 : サンゴ骨材を 用いたコンクリートの施工性および而久性に関する 検討, セメント・コンクリート論文集, Vol.71, No.1, pp.394-401, 2017.

9) 枷場重正, 川村満紀, 山田祐定, 高桑二郎 : 練り混 ぜ水に海水を使用したコンクリートの諸性質につい て, 材料, Vol.24, No.260, pp.425-431, 1975.5

10）西田孝弘，大即信明，鬼塚良介，Wanchai Yodsudjai， 横倉順治 : 環太平洋地域の低品質粗骨材を使用した コンクリートの強度および物質透過抵抗性に関する 研究, 土木学会論文集, No.746/V-61, pp.103-114, 2003.11

11) 関 博, 大即信明: コンクリート用骨材としての沖 縄産骨材の特性について, 港湾技研資料, No.240, pp.1-19, 1976.9

12) 新井 暢, 中村成春, 桝田佳寛, 阿部道彦: 再生細 骨材コンクリートの強度及び変形性状, コンクリー 卜工学年次論文集, Vol.19, No.1, pp.1081-1086, 1997.

13) 河野克哉, 岡本亨久, 柴田辰正, 石川雄康 : 超軽量 骨材を用いたコンクリートの自己収縮ならびに乾燥 収縮, コンクリート工学年次論文集, Vol.20, No.2, pp.43-48, 1998.

14) 五十嵐心一, 川村満紀, 神崎暁史 : 軽量骨材の使用 による高強度コンクリートの自己収縮の低減効果, コンクリート工学年次論文集, Vol.24, No.1, pp.399-404, 2002.

15) 黒岩秀介, 陣内 浩, 並木 哲, 名和豊春 : 人工軽 量骨材による高強度コンクリートの自己収縮低減, 大成建設技術センター報，第46 号， 2013 。

16) 山田 宏, 片平 博, 渡辺博志: 粗骨材の収縮特性 の評価に関する検討, 土木学会論文集 E2（材料・コ ンクリート構造），Vol.68, No.1, pp.63-71， 2012. 
17) 土木学会 : 人工軽量骨材コンクリート設計施工マニ ユアル，コンクリート・ライブラリー，第 56 号， 1985.5

18) 高野智弘, 寺田哲美, 山中誠 : 水中環境下のコンク リートならびにモルタルの耐摩耗性について，コン
クリート工学年次論文集，Vol.31，No.1，pp.709-714， 2009.

(Received December 24, 2019)

(Accepted August 18, 2020)

\section{EFFECTS OF LIMESTONE AGGREGATE DERIVED FROM CORALS ON PROPERTIES OF SELF-COMPACTING CONCRETE MIXED WITH SEAWATER}

\section{Hiroshi TAKENAKA, Osamu TANIGUCHI, Ryoichi TANAKA, Kazuhide YONAMINE, Toru YAMAJI and Osamu KIYOMIYA}

Experimental studies were conducted on fundamental properties, shrinkage properties, thermal properties, and wear properties of self-compacting concrete mixed with seawater and limestone aggregate derived from corals assuming use on isolated islands. As a result, the concrete using this aggregates with many voids had excellent fluidity, moderate segregation resistance, and the same strength development as when using ordinary aggregates. In addition, shrinkage and thermal expansion coefficient were smaller than that of concrete using ordinary aggregate. Furthermore, even when coral aggregate was used, abrasion resistance of concrete equivalent to that when using ordinary aggregate could be secured by setting the water cement ratio and unit coarse aggregate volume small. 